Article

\title{
Phytochemical Characterization, Antioxidant Activity, and Cytotoxicity of Methanolic Leaf Extract of Chlorophytum comosum (Green Type) (Thunb.) Jacq
}

Igor V. Rzhepakovsky ${ }^{1}$ D, David A. Areshidze ${ }^{2,3}$, Svetlana S. Avanesyan ${ }^{1}$, Wolf D. Grimm ${ }^{4}$, Natalya V. Filatova ${ }^{3}$, Aleksander V. Kalinin ${ }^{5}$, Stanislav G. Kochergin ${ }^{6}$, Maria A. Kozlova ${ }^{2}$, Vladimir P. Kurchenko ${ }^{1,7}$, Marina N. Sizonenko ${ }^{1}$, Alexei A. Terentiev ${ }^{3,8}$, Lyudmila D. Timchenko ${ }^{1}$, Maria M. Trigub ${ }^{3}$, Andrey A. Nagdalian ${ }^{1,9, *(D)}$ and Sergei I. Piskov ${ }^{1}$ D

1 Faculty of Medicine and Biology, North-Caucasus Federal University, Pushkina Street 1, 355000 Stavropol, Russia; 78igorr@mail.ru (I.V.R.); s.avanesan@yandex.ru (S.S.A.); kurchenko@tut.by (V.P.K.); risha_veresk@mail.ru (M.N.S.); 1_timchenko@mail.ru (L.D.T.); piskovsi77@mail.ru (S.I.P.)

2 Laboratory of Cell Pathology, Research Institute of Human Morphology, Russian Academy of Medical Science, Tsyurupa Street 3, 117418 Moscow, Russia; labcelpat@mail.ru (D.A.A.); ma.kozlova2021@outlook.com (M.A.K.)

3 Institute of Problems of Chemical Physics, Russian Academy of Sciences (IPCP RAS), Academician Semenov Avenue 1, 142432 Chernogolovka, Russia; natasha55555@yandex.ru (N.V.F.); alexei@icp.ac.ru (A.A.T.); trigub.m@gmail.com (M.M.T.)

check for updates

Citation: Rzhepakovsky, I.V.; Areshidze, D.A.; Avanesyan, S.S.; Grimm, W.D.; Filatova, N.V.; Kalinin, A.V.; Kochergin, S.G.; Kozlova, M.A.; Kurchenko, V.P.; Sizonenko, M.N.; et al. Phytochemical Characterization, Antioxidant Activity, and Cytotoxicity of Methanolic Leaf Extract of Chlorophytum comosum (Green Type) (Thunb.) Jacq. Molecules 2022, 27, 762. https://doi.org/ $10.3390 /$ molecules 27030762

Academic Editor: Lillian Barros

Received: 18 December 2021

Accepted: 18 January 2022

Published: 24 January 2022

Publisher's Note: MDPI stays neutral with regard to jurisdictional claims in published maps and institutional affiliations.

Copyright: (C) 2022 by the authors. Licensee MDPI, Basel, Switzerland. This article is an open access article distributed under the terms and conditions of the Creative Commons Attribution (CC BY) license (https:// creativecommons.org/licenses/by/ $4.0 /)$.
4 Faculty of Health, Witten/Herdecke University, Alfred-Herrhausen-Straße 50, 58448 Witten, Germany; prof-wolf.grimm@yahoo.de

5 Stavropolsky Antiplague Scientific Research Institute (SAPRI), Sovetskaya Street 13/15, 355106 Stavropol, Russia; ruslankalmykov777@yandex.ru

6 InCome Ltd., Tukhachevskogo Street 21, 355040 Stavropol, Russia; wwwstas@yandex.ru

7 Belarusian State University, Nezavisimosti Avenue 4, 220030 Minsk, Belarus

8 Medicinal Chemistry Research and Education Center, Moscow Region State University, Very Voloshinoi Street, 141014 Mytishchi, Russia

9 Saint Petersburg State Agrarian University, Peterburgskoye Shosse 2, 196605 Saint Petersburg, Russia

* Correspondence: geniando@yandex.ru or anagdalian@ncfu.ru

\begin{abstract}
Chlorophytum genus has been extensively studied due to its diverse biological activities. We evaluated the methanolic extract of leaves of Chlorophytum comosum (Green type) (Thunb.) Jacques, the species that is less studied compared to $C$. borivilianum. The aim was to identify phytoconstituents of the methanolic extract of leaves of $C$. comosum and biological properties of its different fractions. Water fraction was analyzed with matrix-assisted laser desorption/ionization time-of-flight (MALDITOF) mass spectrometry. Nineteen compounds belonging to different chemical classes were identified in the methanolic extract of leaves of $C$. comosum (Green type) (Thunb.) Jacques. In addition to several fatty acids, isoprenoid and steroid compounds were found among the most abundant constituents. One of the identified compounds, $4^{\prime}$-methylphenyl-1C-sulfonyl- $\beta$-D-galactoside, was not detected earlier in Chlorophytum extracts. The water fraction was toxic to HeLa cells but not to Vero cells. Our data demonstrate that methanolic extract of leaves of $C$. comosum can be a valuable source of bioactive constituents. The water fraction of the extract exhibited promising antitumor potential based on a high ratio of HeLa vs. Vero cytotoxicity.
\end{abstract}

Keywords: Chlorophytum comosum; antioxidant activity; cytotoxicity; herbal medicine; biological active substances

\section{Introduction}

Chlorophytum comosum belongs to the genus Chlorophytum that covers more than 200 species [1-3]. A number of Chlorophytum species are referred to as medicinal herbs in the traditional medicine of India [4,5], China [6,7] and Africa [8]. Several species are known as a 
source of 'Safed musli', a major ingredient of herbal preparations with immunomodulatory, adaptogenic, aphrodisiac and other activities $[2-4,9,10]$.

Due to its long use in history in traditional medicine, the Chlorophytum genus has drawn the attention of researchers in evidence-based medicine. Preparations obtained from different Chlorophytum species have been studied for their biological activity and were found to possess immunomodulatory and anti-infectious [11-16], antibacterial [17], antinociceptive [18] and antioxidant activities [19-26] to improve male sexual health [27-34], to ameliorate manifestations of diabetes, hyperglycemia and hyperlipidemia [35-38] or toxic hepatic and testicular impairments $[20,39,40]$.

The antitumor potential of the Chlorophytum genus has also been studied. Most studies have been performed in vitro with the use of herbal extracts, their fractions or purified constituents. Butanol extract of $C$. comosum roots was shown to inhibit proliferation and induce apoptosis in four cell lines, mostly of hematological origin. Corresponding to the provided data on the concentrations used in the study, the antiproliferative effect of the extract for T-cell leukemia CCRF-HSB-2 cells exceeded that of Actinomycin D 7to 8-fold [41]. Crude methanol/dichloromethane extract and butanol (saponin) fraction of methanolic extract of $C$. borivilianum roots have been demonstrated to have relatively low toxicity with IC50 $>100 \mathrm{mkg} / \mathrm{mL}$ to three solid tumor cell lines [22]. Similar data were obtained for promyelocytic leukemia HL-60 cells treated with methanolic extracts or saponin fractions of roots of five Chlorophytum species [4].

Water extract of $C$. borivilianum roots was examined for antitumor activity in vivo. It has been shown that the extract suppressed the onset and progression of skin tumors induced by carcinogen/promoter application [25].

Phytochemistry studies have revealed compounds of various chemical classes to present in Chlorophytum plants. Both common and specific constituents have been isolated from underground parts of Chlorophytum species with the use of different extraction and fractionation methods $[17,42-45]$. The major class of phytochemicals of the Chlorophytum genus is represented by a versatile group of saponins that exert different biological activities [1,37,46-52].

In vitro cytotoxicity, studies were carried out with saponins purified from butanol fractions obtained from methanolic extracts of underground parts of C. comosum [46,47] and rhizomes of $C$. malayense [48] as well as ethanolic extract of roots of $C$. borivilianum [49]. Saponins from C. comosum inhibited tumor promoter effects and exhibited cytotoxicity towards cervical carcinoma HeLa cells, though quantitative data on cytotoxicity were not provided [47]. In seven cell lines originating from solid tumors, C. malayense saponin chloromaloside A has been shown to exert a cytotoxic effect that was weaker than that of microtubule destabilizing agent colchicine and topoisomerase II inhibitor ellipticine [48]. One of five spirostane-type saponins purified from C. borivilianum, borivilianoside $\mathrm{H}$, was found to be highly toxic to colon tumor cell lines, much less toxic compared to microtubule targeting antitumor compound paclitaxel [49].

Studies published so far have been performed almost exclusively using the underground parts of plants, though secondary metabolite biosynthesis is believed to take place both in leaves and roots based on gene expression profiles [53]. Some of the leaf extracts of C. borivilianum obtained with solvents of different polarities exhibited antioxidant properties comparable to those of ascorbic acid and quercetin [54]. Aqueous, methanolic and ethanolic extracts of $C$. borivilianum leaves were shown to be toxic to BHK-21 cells [55] that are derived from normal newborn hamster fibroblasts [56]. Since crude leaf extracts are toxic to normal cells, they can be hardly considered as an efficient anticancer remedy and their biological activities have to be evaluated after further fractionation. Recently, ethanolic root and leaf extracts of C. comosum were studied and shown to be toxic to MCF-7, A549 and H1299 cells [57].

Here, we present the study of phytochemistry and biological activities of fractions obtained with serial fractionation of methanolic extract of $C$. comosum leaves. The extract was found to comprise a number of bioactive compounds with known biological activities. 
$n$-Hexane, chloroform, $n$-butanol and water fractions proved to be substantially different in their content and activity. Chloroform and $n$-butanol fractions possess the majority of antioxidant properties, whereas water fractions exhibited the most promising antitumor potential.

\section{Results}

\subsection{GC-MS Analysis}

The GC-MS analysis of methanolic leaf extract of C.comosum (Figure 1) revealed nineteen constituents representing 100\% of the extract. The detailed tabulations of GCMS analysis of the extract are given in Table 1 . Three major compounds with maximum content included 9,12-octadecadienoic acid (Z,Z)- (41.27\%), neophytadiene (9.57\%), and $n$-hexadecanoic acid (7.66\%). Sucrose, $\gamma$-sitosterol, octadecanoic acid, 9,12-octadecadienoic acid (Z,Z)-, 2-hydroxy-1-(hydroxymethyl) ethyl ester, stigmasterol, 4'-methylphenyl-1Csulfonyl-.beta.-D-galactoside, dihydroxyacetone, 3,7,11,15-tetramethyl-2-hexadecen-1-ol, hexadecanoic acid, 2-hydroxy-1-(hydroxymethyl) ethyl ester, and methyl (Z)-5,11,14,17eicosatetraenoate were present at levels of circa $2-4.5 \%$ each. The residual compounds detected by GC-MS comprised less than $9 \%$ in total.

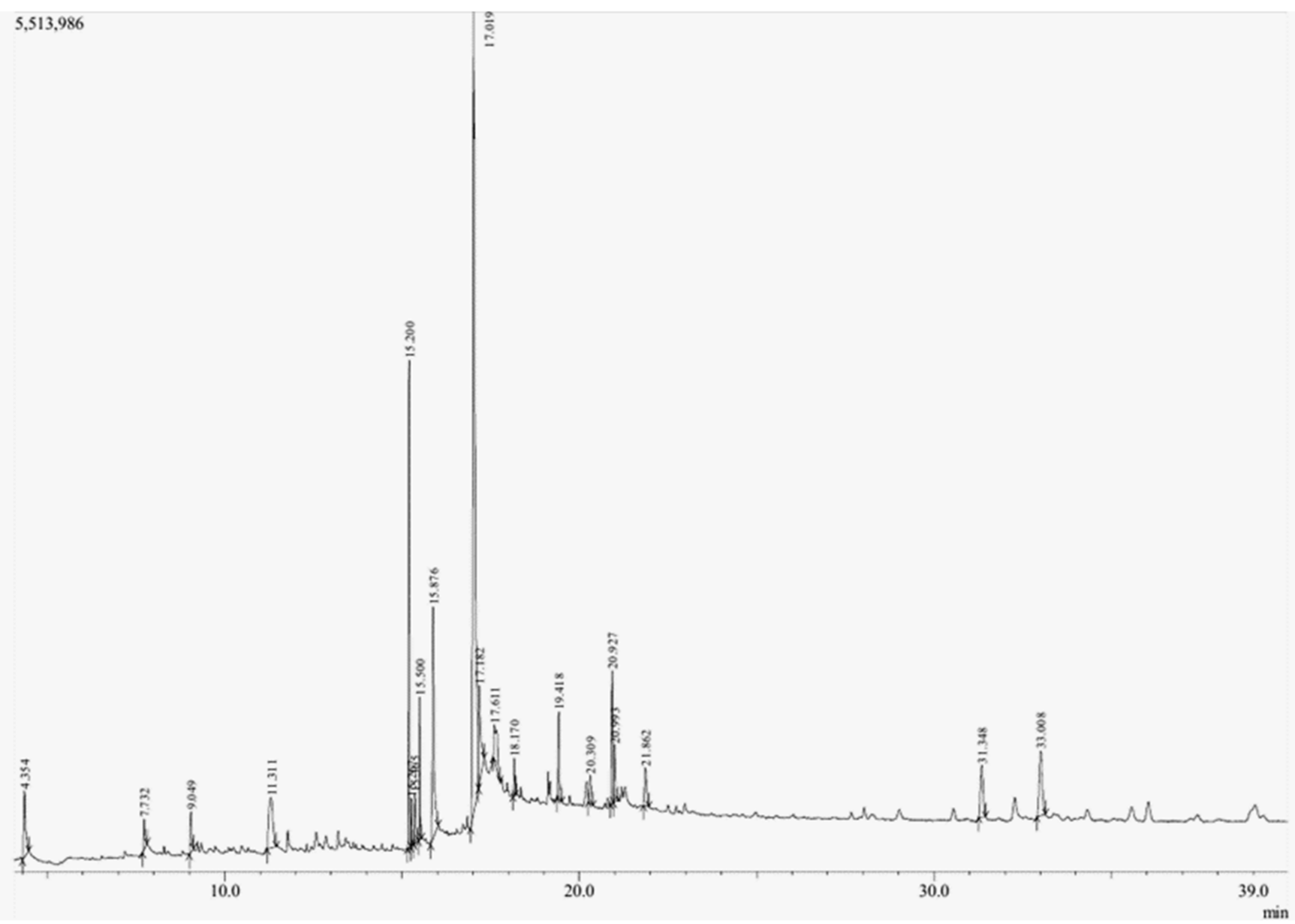

Figure 1. GC-MS chromatogram of the methanolic extract of leaves of Chlorophytum comosum (Green type). 
Table 1. Phytoconstituents detected in the methanolic extract from leaves of Chlorophytum comosum (Green type).

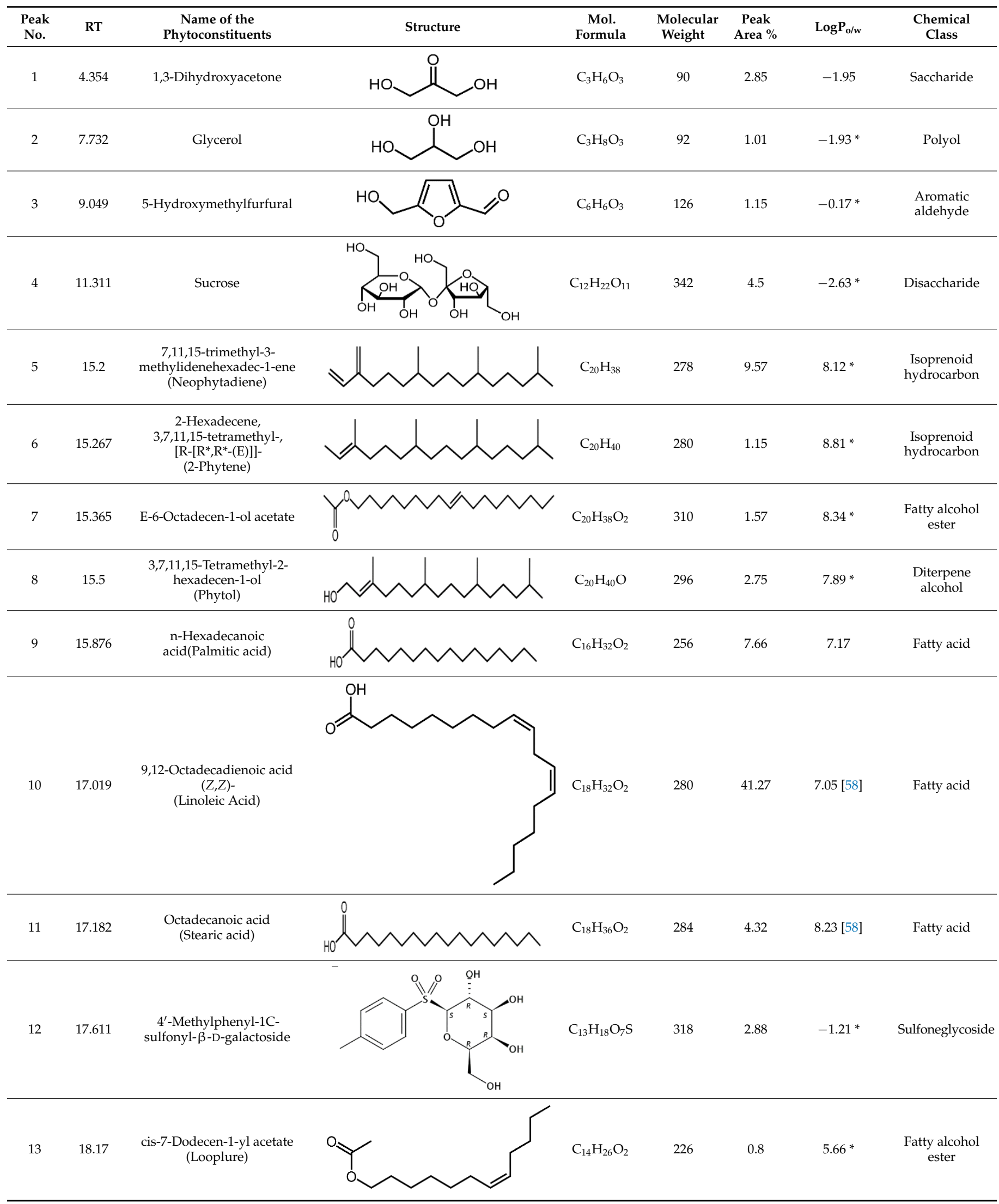


Table 1. Cont.

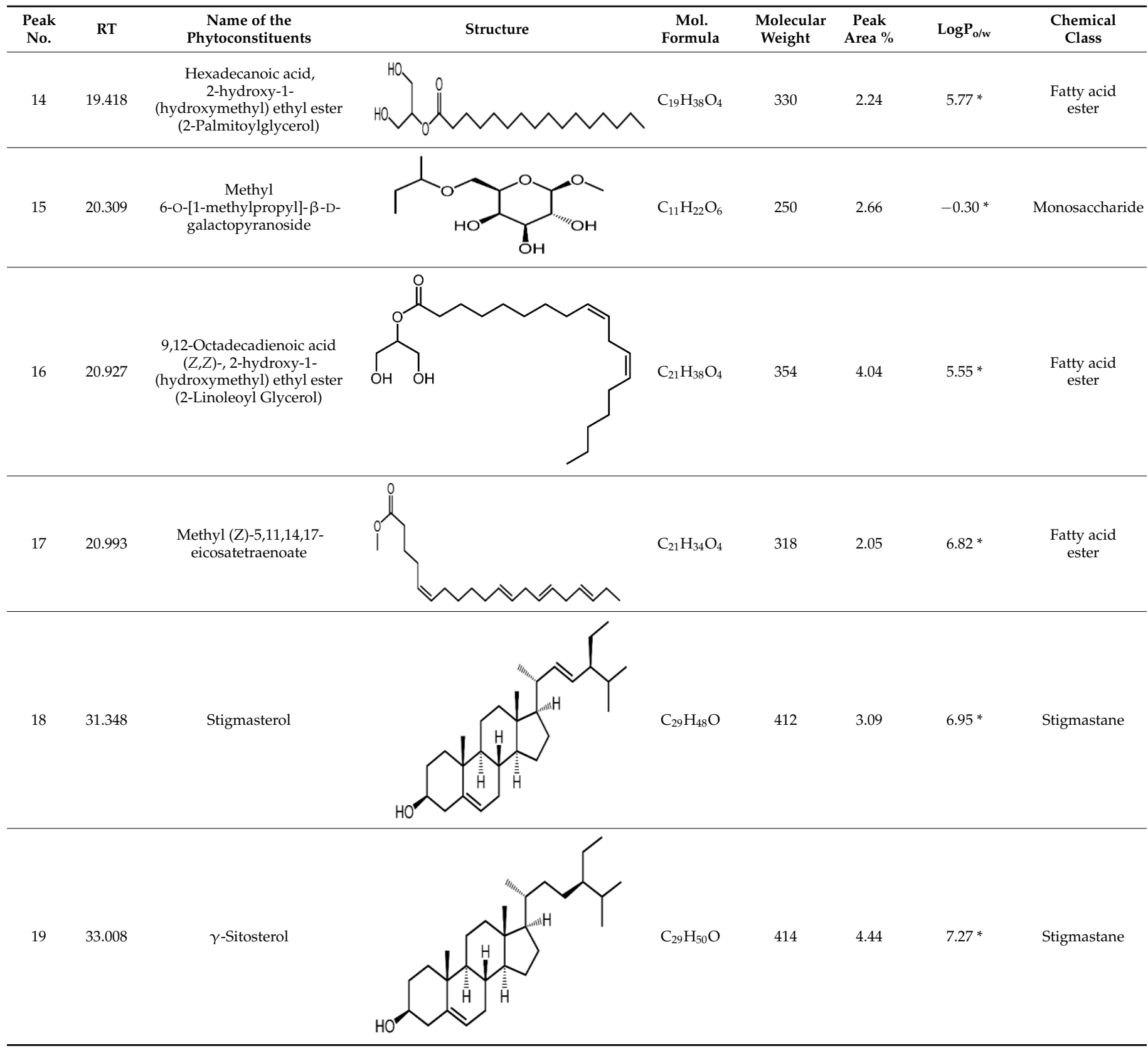

*-Calculated with ALOGPS software [59].

\subsection{Phytochemical Screening of Fractions}

All fractions of the methanolic extract were shown to contain phenolic compounds, flavonoids, chlorophylls, carotenoids, tannins and reducing sugars (Table 2). The largest amounts of chlorophylls and carotenoids were found in the $n$-hexane and chloroform fractions, whereas phenolic compounds and simple carbohydrates were most abundant in the $n$-butanol fraction and, to a lesser extent, yielded in the chloroform fraction. 
Table 2. Total bioactive compounds found in fractions of the methanolic extract of leaves of Chlorophytum comosum (Green type), mean $\pm \mathrm{SD}(n=10)$.

\begin{tabular}{|c|c|c|c|c|}
\hline Bioactive Compounds & $n$-Hexane Fraction & Chloroform Fraction & n-Butanol Fraction & Water Fraction \\
\hline Relative content of dry matter, $\%$ & $19.9 \pm 0.5$ & $22.8 \pm 0.57$ & $23.4 \pm 0.4$ & $33.9 \pm 0.7$ \\
\hline $\begin{array}{c}\text { Concentration of extracted matter } \\
\text { in DMSO, } \mathrm{mg} / \mathrm{mL}\end{array}$ & $50 \pm 2.0 *$ & $100 \pm 2.0$ & $100 \pm 3.0$ & $100 \pm 3.0$ \\
\hline $\begin{array}{l}\text { Total phenolic content (TPC), mg } \\
\text { GAE } / \mathrm{mL}\end{array}$ & $1.08 \pm 0.02$ & $5.6 \pm 0.1$ & $19.9 \pm 0.5$ & $0.51 \pm 0.02$ \\
\hline Tannins, mg/mL & $1.73 \pm 0.04$ & $4.22 \pm 0.1$ & $15.75 \pm 0.4$ & $1.77 \pm 0.03$ \\
\hline $\begin{array}{l}\text { Total flavonoid content (TFC), mg } \\
\text { QE } / \mathrm{mL}\end{array}$ & $0.05 \pm 0.001$ & $\mathrm{ND}^{* *}$ & $0.09 \pm 0.001$ & ND \\
\hline Chlorophyll a, mg/mL & $3.16 \pm 0.05$ & $0.16 \pm 0.004$ & ND & ND \\
\hline Chlorophyll b, mg/mL & $1.77 \pm 0.02$ & $0.26 \pm 0.01$ & ND & ND \\
\hline Carotenoids, mg/mL & $0.74 \pm 0.02$ & $0.62 \pm 0.02$ & ND & ND \\
\hline Reducing sugars, mg/mL & $1.53 \pm 0.03$ & $9.18 \pm 0.1$ & $22.2 \pm 0.5$ & $1.28 \pm 0.02$ \\
\hline
\end{tabular}

* The extracted matter in the $n$-hexane fraction had low solubility in DMSO. ${ }^{* *} \mathrm{ND}$, not detected.

In the water fraction, little amounts of phenolic compounds and simple carbohydrates were detected; most of the remaining matter in the fraction was not identified.

\subsection{Antioxidant Activity of Fractions}

The chloroform and $n$-butanol fractions exhibit the highest reducing power and total antioxidant activity (Table 3). The antioxidant properties have to be attributed to phenolic compounds that are most abundant in these fractions.

Table 3. Antioxidant activity of the fractions of methanolic extract from leaves of Chlorophytum comosum (Green type), mean \pm SD $(n=10)$.

\begin{tabular}{ccccc}
\hline Antioxidant Activity Criterion & $\begin{array}{c}n \text {-Hexane } \\
\text { Fraction }\end{array}$ & $\begin{array}{c}\text { Chloroform } \\
\text { Fraction }\end{array}$ & $\begin{array}{c}n \text {-Butanol } \\
\text { Fraction }\end{array}$ & $\begin{array}{c}\text { Water } \\
\text { Fraction }\end{array}$ \\
\hline $\begin{array}{c}\text { Reducing power, } \\
\text { mg AAE eq/mL }\end{array}$ & $0.39 \pm 0.01$ & $6.25 \pm 0.2$ & $33.1 \pm 2.5$ & $0.58 \pm 0.07$ \\
\hline ABTS radical scavenging activity, $\mathrm{mg} \mathrm{TEs} / \mathrm{mL}$ & $0.27 \pm 0.01$ & $0.36 \pm 0.01$ & $0.81 \pm 0.05$ & $0.27 \pm 0.02$ \\
\hline Total antioxidant activity (TAA), $\mathrm{mg} \mathrm{AAE} \mathrm{eq/mL}$ & $9.7 \pm 0.32$ & $17.4 \pm 0.6$ & $35.9 \pm 4.5$ & $1.8 \pm 0.9$ \\
\hline
\end{tabular}

\subsection{Cytotoxicity}

Human cervical carcinoma cell line HeLa and non-cancerous kidney epithelium cells of Cercopithecus aethiops Vero were used for the cytotoxicity studies (Figure 2). Chloroform fraction proved to be the most toxic to cells, with relatively higher (appr. two-fold) toxicity towards HeLa cells. $n$-Hexane and $n$-butanol fractions exhibited similar toxicity to both HeLa and Vero cells. On the other hand, the water fraction was shown to have a very high ratio of Hela to Vero toxicity. While the viability of HeLa cells was efficiently inhibited with IC50 value of $0.12 \mathrm{mg} / \mathrm{mL}$, Vero cells were not affected by the water fraction at doses up to the maximum concentration limited by toxicity of the solvent. 

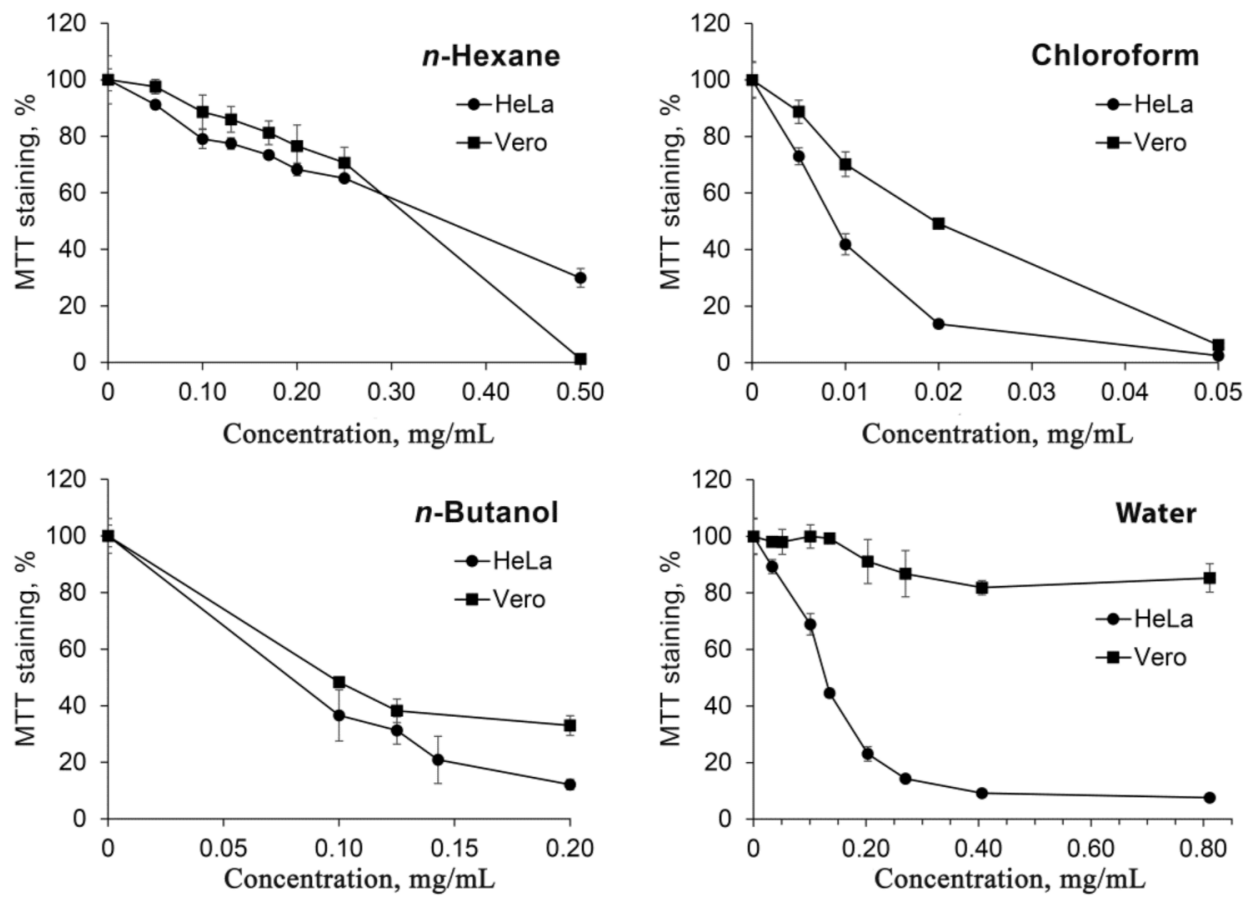

Figure 2. Cytotoxicity of fractions of methanolic extract of leaves of Chlorophytum comosum (Green type).

\subsection{MALDI-TOF Mass Spectrometry of Water Fraction of Methanolic Extract of Leaves of C. comosum}

The obtained mass spectra of the water fraction contain signals of different intensities in the range of 500-2200 Da (Figure 3). There were 10 signals with $\mathrm{m} / \mathrm{z}$ up to $1000 \mathrm{Da}$, 19 signals in the range of 1200-1700 Da and one signal of $2173 \mathrm{Da}$ detected. The following signals were characterized by the highest intensity: $681 \pm 5 \mathrm{Da}, 1385 \pm 5 \mathrm{Da}, 1486 \pm 5 \mathrm{Da}$, $1503 \pm 5 \mathrm{Da}$, and $2173 \pm 5 \mathrm{Da}$. Analysis of mass spectrometry data using the BIOPEP$\mathrm{UWM}^{\mathrm{TM}}$ database [60], showed that of water fraction of methanolic extract of leaves of C. comosum may contain peptides with antibacterial, antifungal and anticancer activities, as well as enzyme inhibitors that could determine its activity in cell cultures (Table 4).

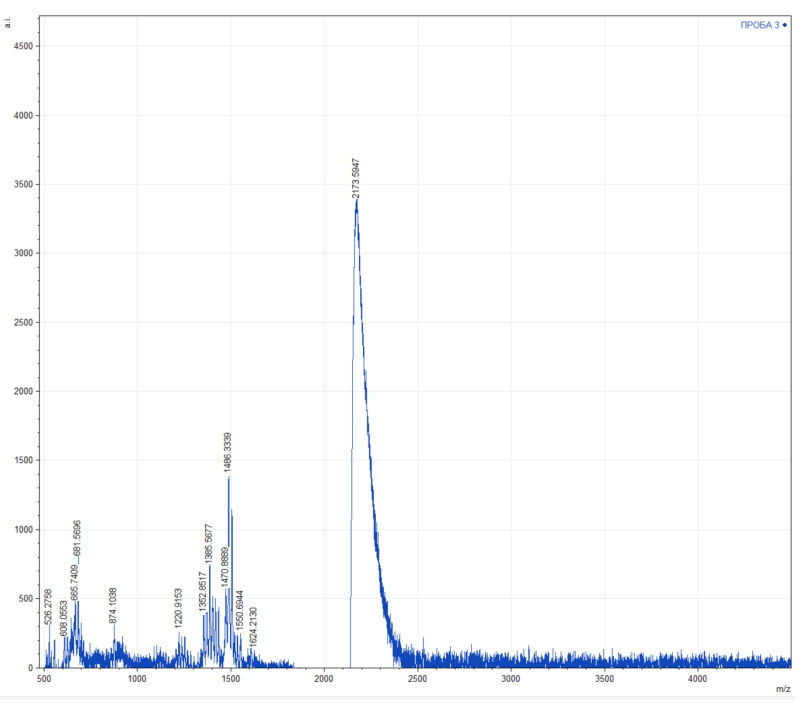

Figure 3. Data of the MALDI-TOF mass spectrometry of water fraction of methanolic extract of leaves of Chlorophytum comosum (Green type). 
Table 4. Characterization of the proteomic analysis of water fraction of methanolic extract of leaves of Chlorophytum comosum (in accordance with the BIOPEP-UWM ${ }^{\mathrm{TM}}$ database).

\begin{tabular}{|c|c|c|c|c|}
\hline Chemical Mass, Da & ID & Sequence & Activity & Int. \\
\hline 681 & - & - & - & 730 \\
\hline- & 8252 & EQRPR & anticancer & - \\
\hline 1385 & - & - & - & 675 \\
\hline- & 3194 & FLPAIAGILSQLF & hemolytic & - \\
\hline- & 8311 & FFVAPFPEVFGK & anticancer & - \\
\hline- & 9291 & KKLFKKILKKL & antifungal & - \\
\hline- & 9466 & FKCRRWQWR & antibacterial & - \\
\hline \multirow[t]{2}{*}{1486} & - & - & - & 1335 \\
\hline & 2979 & KKAVRRQEAVDAL & CaMKII inhibitor & - \\
\hline- & 2989 & KKALRRDEAVDAL & CaMKII inhibitor & - \\
\hline- & 2990 & KKALRRNEAVDAL & CaMKII inhibitor & - \\
\hline- & 2991 & KKALRRQEGVDAL & CaMKII inhibitor & - \\
\hline- & 3190 & SSSKEENRIIPGGI & antibacterial & - \\
\hline- & 5450 & GLFDAIGNLLGGLGLG & antibacterial & - \\
\hline- & 5474 & GLFDIVKKIAGHIA & antibacterial & - \\
\hline- & 8335 & SDIPNPIGSENSEK & antibacterial & - \\
\hline- & 9458 & RWQWRWQWR & antibacterial & - \\
\hline- & 9783 & GEHGGAGMGGGQFQPV & alpha-amylase inhibitor & \\
\hline \multirow[t]{4}{*}{-} & 9784 & GEHGGAGMGGGQFQPV & pancreatic lipase inhibitor & \\
\hline & 9785 & GEHGGAGMGGGQFQPV & lipoxygenase inhibitor & \\
\hline & 9786 & GEHGGAGMGGGQFQPV & cyclooxygenase- 1 inhibitor & \\
\hline & 9787 & GEHGGAGMGGGQFQPV & cyclooxygenase-2 inhibitor & \\
\hline 1503 & - & - & - & 1083 \\
\hline- & 2987 & KKALRREEAVDAL & CaMKII inhibitor & - \\
\hline- & 3006 & KKALYRQEAVDAL & CaMKII inhibitor & - \\
\hline- & 3008 & KKALRYQ̄EAVDAL & CaMKII inhibitor & - \\
\hline- & 3920 & GLFDIIKKIAESIG & antibacterial & - \\
\hline- & 5454 & GLFDIIKKIAESIG & antibacterial & - \\
\hline- & 5457 & LDIVKKVVGAFGSLG & antibacterial & - \\
\hline- & 9294 & WKLFKKILKWL & antifungal & - \\
\hline- & 9295 & WKLFKKILKWL & hemolytic & - \\
\hline- & 9313 & WKLFKKILKKLG & antifungal & - \\
\hline- & 9314 & WKLFKKILKKLG & hemolytic & - \\
\hline \multirow[t]{3}{*}{2173} & - & - & - & 2403 \\
\hline & 3822 & GLLRRLRKKIGEIFKKYG & antibacterial & - \\
\hline & 7053 & KWKLFKKIKFLHSAKKF & anticancer & - \\
\hline
\end{tabular}

\section{Discussion}

A number of compounds that were identified in the methanolic extract of leaves of Chlorophytum comosum (Green type) have been well characterized.

As is seen from the GC-MS data, unsaturated fatty acids are among the major constituents of the methanolic extract. Linoleic acid (appr. 41\% of GC-MS chromatogram area, Figure 1) is considered an essential nutrient with a variety of physiological functions, though there are concerns about the consequences of its excessive consumption for human health. [61,62]. Palmitic acid $(7.66 \%)$ is one of the most abundant saturated fatty acids in organisms. Its homeostasis is tightly controlled, and its imbalance is related to different physiopathological conditions [63]. Stearic acid (4.32\%), synthesized from palmitic acid, is one the most abundant saturated fatty acid in the Western diet. Its effects on cardiometabolic risk markers seem to be different from that of palmitic acid, and a stearic acid-reach diet could be beneficial compared to the ones that are rich with other saturated fatty acids $[64,65]$.

Sucrose $(4.5 \%)$ is an important nutrient energy source, but its imbalance or excessive consumption has multiple deleterious effects on human health [66,67]. It has been also demonstrated to exert pain preventive effect on infants $[68,69]$. 
Some of the constituents of C. comosum methanolic leaf extract have been shown to exhibit therapeutic potential. For the second most abundant compound detected with GC-MS, neophytadiene (appr. 10\%), anti-inflammatory, antioxidant and cardioprotective activities have been demonstrated [70].

$\gamma$-Sitosterol (4.44\%) was shown to exert hypocholesterolemic, antidiabetic effects [71].

Stigmasterol (3.09\%) exerts antitumor [58,72-74], hypolipidemic [75-80], antidiabetic [81,82], antimutagenic [83], antiparasitic [84], and antinociceptive [85] effects. It can also alleviate manifestations of osteoarthritis [86,87], inflammation and autoimmune diseases [88-91], and mitigate central nerve system injuries and disorders in both neuroprotective and function-improving manner [92-98]. In several studies its antioxidant activity was also demonstrated [79,81,89,92-94]. Stigmasterol accumulation, however, can cause cardiac injury [99].

Phytol (2.75\%) possesses antioxidant, antimicrobial, anticancer, antidiabetic, hypolipidemic, immunoadjuvant, anti-inflammatory, antimutagenic, antiteratogenic, antinociceptive, antispasmodic, anticonvulsant, anxiolytic, antidepressant activities; it can be used in cosmetics as an active substance or fragrance material $[100,101]$.

5-Hydroxymethylfurfural (1.15\%) has been found to exert both deleterious (organotoxic, mutagenic, carcinogenic, pro-oxidant) and beneficial (antihypoxic, anticancer, antioxidant, anti-allergen, antisickling) effects on health [102,103].

In addition to compounds identified by GC-MS, the methanolic leaf extract of C. comosum was shown to contain phenolic compounds including tannins that are most abundant in the $n$-butanol fraction (Table 2). Reducing sugars were also found at the highest levels in the $n$-butanol fraction. The chloroform fraction was found to contain two- to three-fold less phenolic compounds and reducing sugars, and $n$-hexane and water fractions had the least amounts of these constituents. Flavonoids were detected at low levels in $n$-hexane and $n$-butanol fractions. The larger part of chlorophylls was extracted from the methanolic extract by $n$-hexane; much lesser chlorophylls were also detected in chloroform fractions. Carotenoids were found in $n$-hexane and chloroform fractions at appr. equal levels.

The antioxidant activity of different fractions of the methanolic leaf extract of C. comosum (Table 3) was found to be partially related to the bioactive compound content. The highest reducing power, radical scavenging activity, and total antioxidant activity were found in $n$-butanol and chloroform fractions that correlated with the highest content of phenolic compounds. On the other hand, the reducing power and total antioxidant activity of $n$-hexane and water fractions did not correspond to the phenolic compounds content since water fraction had appr. 1.5-fold higher reducing power and appr. 5-fold lower total antioxidant activity, while both fractions contained similar levels of total phenolics and tannins. It is generally accepted that the antioxidant activity corresponds to the total phenolic content, but in some cases, controversial data were reported suggesting that antioxidant activity might be attributed to antioxidants other than compounds defined as total phenolics [104,105].

The cytotoxicity studies have revealed that the constituents of water fraction have very high toxicity to cancerous HeLa cells compared to non-cancerous Vero cells. In fact, there was no apparent toxicity of water fraction towards Vero cells (Figure 2). The chloroform fraction was shown to be most toxic to cells, but the selectivity towards HeLa cells was significantly lower compared to that of the water fraction.

The data obtained recently with use of $n$-butanol processed ethanolic extracts of defatted roots and leaves of $C$. comosum demonstrated that the extracts were toxic to breast (MCF-7) and lung cancer (A549 and H1299) cell lines but not to the L-132 cell line [57]. Though L-132 (ATCC ${ }^{\circledR}$ CCL-5 ${ }^{\mathrm{TM}}$ ) cells cannot be considered non-cancerous since they have signs of HeLa contamination [106,107], these results, together with the data presented herein, suggest that C. comosum phytoconstituents can possess promising antitumor activity. Moreover, our data demonstrate that the selective antitumor compounds reside in the fraction obtained after successive removal of $n$-hexane-, chloroform- and $n$ butanol-soluble material. 
The total phenolic content of root and leaf ethanolic extracts of C. comosum was in good agreement with their antioxidant activity but had poor correlation with cytotoxicity [57]. Our data obtained after more fractionation steps displayed evidence that cytotoxicity of fractions of methanolic leaf extract of $C$. comosum has no correlation with found bioactive compounds or antioxidant activity.

Further considering active substances that can be responsible for the observed cytotoxicity profile of water fraction, one could suggest that, because of negative $\log \mathrm{P}_{\mathrm{o}} / \mathrm{w}$ values, some constituents of the methanolic extract (Table 1) could be present in water fraction. Unfortunately, cytotoxic activity demonstrated so far for that compound does not support any conclusions about an active substance to which the antitumor potential of water fraction could be attributed.

1,3-Dihydroxyacetone, the compound commonly used in sunless tanning products, was shown to be toxic to transformed HEK293T cells [108], A375P melanoma cells [109], and non-cancerous HaCaT cells $[110,111]$. The experimental settings in the mentioned papers were different, and it is not possible to conclude if dihydroxyacetone could be more toxic towards cancerous than to normal cells. 5-Hydroximethylfurfural, one of the toxicants produced during food processing, exerted moderate cytotoxicity, with IC50 values of millimolar range, to both cancerous and non-cancerous cells [112-114].

Glycerol is one of the cryoprotectants that is quite toxic to cells at $37^{\circ} \mathrm{C}$ even under short exposure time $[115,116]$, but it exhibits general cytotoxicity regardless of the origin of cells.

Sucrose is well tolerated by cells and affects the protein glycosylation processes rather than the cell viability [117].

The sulfone glycoside $4^{\prime}$-methylphenyl-1C-sulfonyl- $\beta$-D-galactoside is quite a rare phytoconstituent. To our knowledge, there is the only MS study that identified $4^{\prime}$-methylphenyl$1 C$-sulfonyl- $\beta$-D-galactoside in Rhodiola Rosea [118]. The biological activity of this compound is not known. The compound was synthesized in a survey of antimalarial agents, but no further studies were published since 1964 [119,120]. A structural analog of the compound with methylphenyl-sulfonyl moiety bound to the oxygen of the 6C atom, inhibited the sugar uptake process in bacteria [121].

Methyl 6-O-[1-methylpropyl]- $\beta$-D-galactopyranoside was found as one of four most abundant constituents in the ethanolic leaf extract of the Kofat cultivar of Catha edulis. The cytotoxicity studies did not reveal any selectivity in toxicity of the extracts towards cancer cells compared to normal fetal lung fibroblast [122].

MALDI-TOF mass spectrometry of the water fraction has revealed a number of compounds that may belong to bioactive peptides. The EQRPR pentapeptide, identified in rice bran, was shown to be toxic to several cancer cell lines, though at relatively high concentrations [123]. The peptide FFVAPFPEVFGK and its close analogs were found in skin extract of amphibians and hydrolysates of casein [124]. It was found to inhibit several proteinases involved in cancer progression though it did not exhibit cytotoxicity towards cancer cells [125]. The KWKLFKKIKKIKFLHSAKKF peptide, corresponding to CancerPPD database data [126], possesses mild cytotoxic activity against several cancer cell lines with IC50 values ranging at $65-100 \mu \mathrm{M}$. At the same time, this peptide is an artificial chimera of two antibacterial peptides of Hyalophora cecropia and Xenopus laevis [127], hence it is hardly possible that this compound is naturally produced by C. comosum.

Thus, the water fraction of the methanolic extracts of leaves of C. comosum contains compound(s) that have highly selective toxicity towards cancer cells. This anti-cancer cytotoxicity is apparently unrelated to antioxidant activity. Active compounds of the water fraction may be presented by both small molecules and bioactive peptides.

\section{Materials and Methods}

\subsection{Chemicals}

Methyl alcohol 99.9\%, n-hexane 95\%, chloroform 99\%, n-butanol 99\%, dimethyl sulfoxide (DMSO) $99.7 \%$, aluminum chloride $99.9 \%$, sodium acetate $>99 \%$, quercetin, ace- 
tone $>99.5 \%$, picric acid $\geq 98.0 \%$, dextrose $99.5 \%$, sodium carbonate $99.5 \%$, phosphate buffered saline ( $\mathrm{pH} 7.2$ at $25{ }^{\circ} \mathrm{C}$ ), potassium ferricyanide (III), trichloroacetic acid, $\alpha$ Cyano-4-hydroxycinnamic acid (for MALDI-TOF MS), acetonitrile $\geq 99.0 \%$, iron (III) chloride $99 \%$, ascorbic acid $\geq 99 \%$, sulfuric acid $99.9 \%$, sodium phosphate $96 \%$, ammonium molybdate, potassium persulfate $\geq 99.0 \%, 2,2^{\prime}$-azino-bis(3-ethylbenzothiazoline-6-sulfonic acid) diammonium salt (ABTS), 6-hydroxy-2,5,7,8-tetramethylchroman-2-carboxylic acid (Trolox) 97\%, Folin-Denis' reagent, gallic acid, tannin and chemical standards were purchased from Sigma-Aldrich.

EMEM and DMEM incubation media, L-glutamine, essential amino acids mixture, penicillin-streptomycin 100x lyophilized mixture, $0.25 \%$ trypsin solution and $0.02 \%$ versene solution were purchased from PanEco, Ltd. (Moscow, Russia), fetal bovine serum-from BioWest (Nuaillé, France), and MTT (3-(4,5-dimethylthiazole-2-yl)-2,5-diphenyl-tetrazolium bromide)—from Diaem, Ltd. (Moscow, Russia).

\subsection{Plant Material}

Chlorophytum comosum (Green type) (Thunb.) Jacques was kindly provided by the Botanical Garden of the North-Caucasus Federal University. Vegetative propagation of the plant was carried out in the Greenhouse of the Moscow Region State University. The plant was harvested in August 2019.

\subsection{Sample Preparation}

Freshly cut leaves were washed under running tap water for $30 \mathrm{~s}$, chopped with scissors to pieces of 1-2 cm and subjected to freeze-drying. The material was frozen in SE10-45 (TEFCOLD, Viborg, Denmark) at a temperature of minus $39.0-40.0{ }^{\circ} \mathrm{C}$ for $72 \mathrm{~h}$. Subsequent drying was carried out for 27-30 h in a light-protected chamber in LS-500 freeze dryer (Prointech, Puschino, Russia) with average working pressure in the dryer chamber of 90-100 $\mathrm{Pa}$, the condenser temperature minus $47-49^{\circ} \mathrm{C}$. The residual moisture content of the dried material amounted to $5-6 \%$ as was measured using an Ohaus MB 25 moisture meter (Ohaus Corporation, Parsippany, NJ, USA) at a temperature of $100{ }^{\circ} \mathrm{C}$ in an automatic mode.

The lyophilized leaves were ground to a powder with particle size of $1 \mathrm{~mm}$ or less using a VT-1541 VK grinder (Vitek, SuZhou, China). The powdered samples were stored at $4{ }^{\circ} \mathrm{C}$ in a dark hermetically sealed container until testing for no more than one week.

\subsection{Extraction and Fractionation}

Of the powdered lyophilized leaves, $42.0 \mathrm{~g}$ was extracted with $420.0 \mathrm{~mL}$ of methanol for 14 days at room temperature $\left(23 \pm 0.5^{\circ} \mathrm{C}\right)$. The extract was filtered through cheesecloth and paper filters and then dried using a rotary evaporator RV 10 Basic V (IKA, Germany) at a temperature of $45-50{ }^{\circ} \mathrm{C}$ until complete solvent removal $[128,129]$. The yield of dry matter was $7.0 \pm 0.1 \mathrm{~g}$.

The methanolic extract was subjected to fractionation according to Singh et al. (2009) [130] with slight modifications. The extract $(7.0 \mathrm{~g})$ was dissolved in a methanol:water (9:1) mixture and the solution was successively divided into fractions with $n$-hexane, chloroform and $n$-butanol using a separatory funnel. Organic solvents were removed using a rotary evaporator, water from the final aqueous fraction was removed by lyophilization. The resulting dried pellets were dissolved in DMSO to a concentration of $50 \mathrm{mg} / \mathrm{mL}$ for nhexane fraction and $100 \mathrm{mg} / \mathrm{mL}$ for chloroform, $n$-butanol and water fractions.

\subsection{Gas Chromatography-Mass Spectrometry (GC-MS) Analysis of Methanolic Leaf Extract}

Of the powdered lyophilized leaves, $5 \mathrm{~g}$ was extracted with $100 \mathrm{~mL}$ of methanol for $24 \mathrm{~h}$ at room temperature $\left(23 \pm 0.5^{\circ} \mathrm{C}\right)$. The extract was filtered through $0.22 \mu \mathrm{m}$ PTFE syringe filters (Merck Millipore, Burlington, MA, USA).

For GC-MS analysis, a GCMS-QP2010 Ultra (Shimadzu, Japan) system with a DB5MS capillary column (5\% diphenyl - 95\% dimethylsiloxane copolymer, $60 \mathrm{~m}$ long, inner diameter $0.25 \mathrm{~mm}$, film thickness of the stationary phase $0.25 \mu \mathrm{m}$ ) was used. The carrier gas 
(helium) flow rate was $1.38 \mathrm{~mL} / \mathrm{min}$. The temperature program was as follows: isothermal for $4 \mathrm{~min}$ at $100{ }^{\circ} \mathrm{C}$, increased at $15^{\circ} \mathrm{C} / \mathrm{min}$ to $300{ }^{\circ} \mathrm{C}$, isothermal for $26 \mathrm{~min}$. The ionization voltage was $70 \mathrm{eV}$. The scanning speed was $3333 \mathrm{~s}$ over the $30-550 \mathrm{~m} / z$ range. For qualitative analysis of the essential oil components, the NISTO.5a mass spectra library was used.

\subsection{Matrix-Assisted Laser Desorption/Ionization (MALDI) Time-of-Flight (TOF) Mass Spectrometry}

Water fraction was subjected to proteomic analysis using MALDI-TOF mass spectrometry. The solution was centrifuged at $7000 \mathrm{~g}$ for $4 \mathrm{~min}$. The supernatant (1 microliter) was deposited on the MALDI plate. Pretreated and untreated samples were overlaid with 1 microliter of matrix solution (saturated solution of $\alpha$-cyano-4-hydroxycinnamic acid in $50 \%$ acetonitrile and $2.5 \%$ trifluoroacetic acid). The matrix sample was cocrystallized by air drying at room temperature. Measurements were performed with a Microflex mass spectrometer (Bruker Daltonik, Bremen, Germany) using Daltonics FlexControl software (version 3.3.64). Spectra were recorded in the positive linear mode (laser frequency, $60 \mathrm{~Hz}$; ion source 1 voltage, $19.4 \mathrm{kV}$; ion source 2 voltage, $17.3 \mathrm{kV}$; lens voltage, $9.1 \mathrm{kV}$; mass range, 0 to 20,000 Da). The internal calibration was performed using the mass test standard MBT (Bruker Daltonics, Bremen, Germany). For each spectrum, 4000 shots from different positions of the target spot (automatic mode) were collected and analyzed. Protein identification was performed using the BIOPEP-UWM ${ }^{\mathrm{TM}}$ database [60].

\subsection{Determination of Total Phenolics}

The total phenolic content was measured according to Swain and Hillis method [131]. Then, $100 \mu \mathrm{L}$ of a DMSO-dissolved fraction was mixed with $0.5 \mathrm{~mL}$ of the Folin-Denis reagent. After $3 \mathrm{~min}, 1 \mathrm{~mL}$ of $20 \% \mathrm{Na}_{2} \mathrm{CO}_{3}$ was added, and volume of the mixture was brought to $10.0 \mathrm{~mL}$ with distilled water. After incubation in the dark for $90 \mathrm{~min}$, absorbance of the resulting blue complex was measured at $750 \mathrm{~nm}$ using an SF-102 spectrophotometer (NPO Interfotofizika, Moscow, Russia). Gallic acid was used as a standard. The total phenolic content was expressed in $\mathrm{mg}$ equivalent of gallic acid per $1 \mathrm{~mL}$ of sample $(\mathrm{mg}$ GAEs/mL).

\subsection{Determination of Total Tannins}

The total tannin content was determined according to the Price and Butler method [132] with modifications. A DMSO dissolved extract was diluted 500-fold with distilled water to a concentration of $100-200 \mu \mathrm{g} / \mathrm{mL}$. An aliquot of $0.5 \mathrm{~mL}$ of diluted sample was added to $1 \mathrm{~mL}$ of $1 \% \mathrm{FeCl}_{3}$, then the volume was adjusted to $10 \mathrm{~mL}$ with distilled water. After $5 \mathrm{~min}$ incubation at room temperature, the optical density was measured at $720 \mathrm{~nm}$. Tannin was used as a standard.

\subsection{Determination of Total Flavonoids}

The flavonoid content was studied with the aluminum chloride colorimetric method [133] with slight modifications. An aliquot of $50 \mu \mathrm{L}$ of DMSO dissolved extract was mixed with $1.5 \mathrm{~mL}$ of ethanol, $100 \mu \mathrm{L}$ of $10 \%$ aluminum chloride, $100 \mu \mathrm{L}$ of $1 \mathrm{M}$ sodium acetate and $2.8 \mathrm{~mL}$ of distilled water. The resulting mixture was incubated at room temperature for $30 \mathrm{~min}$ in the dark, then absorbance at $415 \mathrm{~nm}$ was read. Quercetin was used as a standard. The total flavonoid content was expressed in $\mathrm{mg}$ equivalent of quercetin per $1 \mathrm{~mL}$ of sample (mg QEs/mL).

\subsection{Determination of Chlorophyll a, Chlorophyll b, and Total Carotenoid}

The content of chlorophylls a and $b$ and total carotenoid was measured spectrophotometrically. The DMSO dissolved samples were diluted 1000 -fold with $80 \%$ acetone and clarified with centrifugation at $10,000 \times g$ at $4{ }^{\circ} \mathrm{C}$ for $15 \mathrm{~min}$. The absorbance of the supernatant was measured at $470 \mathrm{~nm}, 646.8 \mathrm{~nm}$, and $663.2 \mathrm{~nm}$, and the concentrations of 
chlorophyll a, chlorophyll $\mathrm{b}$ and carotenoids $(\mu \mathrm{g} / \mathrm{mL})$ were calculated using equations for $80 \%$ acetone as described [134].

\subsection{Determination of Carbohydrates}

Reducing sugars were measured with the use of alkaline picric acid method $[135,136]$. In brief, $1 \mathrm{~mL}$ of $1 \%$ picric acid was added to $0.5 \mathrm{~mL}$ of a test fraction, then $3 \mathrm{~mL}$ of $20 \%$ sodium carbonate was added. Samples were boiled for $30 \mathrm{~min}$, cooled and adjusted to $10.0 \mathrm{~mL}$ by distilled water. The absorbance was read at a wavelength of $460 \mathrm{~nm}$. Glucose was used as a standard.

\subsection{Ferric Reducing Power Assay}

The assay was carried out as described $[137,138]$ with slight modifications. As such, $10 \mu \mathrm{L}$ of DMSO dissolved fractions was mixed with $2 \mathrm{~mL}$ of $0.2 \mathrm{M}$ sodium phosphate buffer, $\mathrm{pH} 6.6$, and $1 \mathrm{~mL}$ of $1 \%$ potassium ferricyanide. The resulting mixture was incubated at $50{ }^{\circ} \mathrm{C}$ for $20 \mathrm{~min}$. The reaction was terminated by addition of $1 \mathrm{~mL}$ of $10 \%$ trichloroacetic acid. The mixture was centrifuged at $3000 \times g$ for $10 \mathrm{~min}$, then $0.5 \mathrm{~mL}$ of freshly prepared $0.1 \% \mathrm{FeCl}_{3}$ was added to the supernatant, and the absorption was measured at $700 \mathrm{~nm}$. Ascorbic acid was used as a standard. The reducing power was expressed in mg equivalent of ascorbic acid per $1 \mathrm{~mL}$ of sample (mg AAEs/mL).

\subsection{Assessment of Total Antioxidant Activity (TAA)}

The total antioxidant activity was assayed with the use of the phosphomolybdenum method $[138,139]$. As such, $50 \mu \mathrm{L}$ of DMSO dissolved fractions was mixed with $4 \mathrm{~mL}$ of the reagent solution $(0.6 \mathrm{M}$ sulfuric acid, $28 \mathrm{mM}$ sodium phosphate and $4 \mathrm{mM}$ ammonium molybdenum). The mixture was incubated at $95{ }^{\circ} \mathrm{C}$ for $90 \mathrm{~min}$, then cooled to room temperature. The absorbance was measured at $695 \mathrm{~nm}$. Ascorbic acid was used as a standard. The TAA was expressed in mg equivalent of ascorbic acid per $1 \mathrm{~mL}$ of sample (mg AAEs $/ \mathrm{mL}$ ).

\subsection{Trolox Equivalent Antioxidant Capacity (TEAC) Assay}

The assay was carried out according to described by Piskov et al. (2020), Rzhepakovsky et al. (2021) method [140,141]. 2,29-azinobis-(3-ethylbenzothiazoline-6-sulfonic acid) (ABTS) was dissolved in water to a concentration of $7 \mathrm{mM}$. The ABTS ${ }^{\bullet+}$ cationic radical generation was initiated by addition of $1 \mathrm{~mL}$ of $14.7 \mathrm{mM}$ potassium persulfate to $5 \mathrm{~mL}$ of ABTS. The resulting mixture was kept in the dark at room temperature for $24 \mathrm{~h}$ before use. To perform the assay, the ABTS solution was diluted with distilled water to an optical density of $0.70( \pm 0.02)$ at $734 \mathrm{~nm}$, then $5 \mu \mathrm{L}$ of DMSO dissolved fractions were added to $2 \mathrm{~mL}$ of ABTS solution. The absorbance at $734 \mathrm{~nm}$ was measured $3 \mathrm{~min}$ after mixing. Trolox solution at a concentration of $1 \mathrm{mM}$ was used as a standard. The antioxidant capacity was expressed in mg equivalent of Trolox per $1 \mathrm{~mL}$ of sample $(\mathrm{mg}$ TEs $/ \mathrm{mL})$.

\subsection{Cytotoxicity Assay}

Cancer cells HeLa (human cervical epithelioid carcinoma cell line, subclone $\mathrm{M}$ ) and non-cancerous Vero cells (African green monkey renal epithelial cells) were purchased from the Russian Cell Culture Collection (Institute of Cytology RAS, St., Russia). The HeLa and Vero cells were grown in EMEM and DMEM media, respectively. The incubation media were supplemented with $10 \%$ fetal bovine serum, penicillin $(100 \mathrm{U} / \mathrm{mL})$ and streptomycin $(100 \mu \mathrm{g} / \mathrm{mL})$. The cells were cultured at $37^{\circ} \mathrm{C}$ in a humidified atmosphere of $5 \% \mathrm{CO}_{2}$. Cytotoxicity of $C$. comosum fractions was studied with the use of the MTT staining method [142]. Cells were plated in 96-well plates $\left(5 \times 10^{3}\right.$ cells $/$ well). Then, $24 \mathrm{~h}$ after plating, growth medium was replaced by medium containing different quantities of fractions dissolved in DMSO. The final concentration of DMSO did not exceed $1 \%$. Then, $24 \mathrm{~h}$ after addition of samples, $10 \mu \mathrm{L}$ of MTT stock solution $(5 \mathrm{mg} / \mathrm{mL}$ ) was added into each well and plates were incubated for $4 \mathrm{~h}$. The media were then removed and MTT formazan was dissolved 
in DMSO $(100 \mu \mathrm{L} /$ well). The absorption of the samples was read at $570 \mathrm{~nm}$ (reference wavelength $650 \mathrm{~nm}$ ). MTT staining of control samples treated with DMSO was taken as $100 \%$.

\section{Conclusions}

Our data demonstrate that methanolic extract of leaves of Chlorophytum comosum (Green type) (Thunb.) Jacques can be a source of a number of bioactive compounds including those that can be used as dietary supplements as well as constituents with broad biological activity and therapeutic potential. We have found that water fraction of the methanolic extract obtained after successive removal of $n$-hexane, chloroform and $n$-butanol soluble matter comprises compound(s) with high selectivity of cytotoxicity towards cancer cells. The exact nature of this antitumor potential has to be elucidated.

Author Contributions: I.V.R. and D.A.A. designed and performed the experiment; S.S.A., N.V.F. and M.A.K. developed methodology and carried out the experiment; V.P.K. and L.D.T. provided intellectual support; A.V.K. and S.G.K. provided all material resources; M.N.S., A.A.T., M.M.T. and S.I.P. investigated all objects, prepared figures and tables and wrote the manuscript; W.D.G. and A.A.N. were involved in methodology and data analysis, writing and editing of the manuscript. All authors have read and agreed to the published version of the manuscript.

Funding: The work was carried out using the Center for Collective Use of the North Caucasus Federal University (NCFU) with the financial support of the Ministry of Education and Science of the Russian Federation (project RF ---- 2296.61321X0029, Agreement No. 075-15-2021-687). The study of cytotoxicity was carried out within the framework of the State Task of the Ministry of Science and Higher Education of the Russian Federation No. AAAA-A19-119092390041-5. Analytical research and methodology were performed under the contract No. AAAA-A19 119071890015-6 by the Ministry of Science and Higher Education of the Russian Federation. Chemicals and materials used in the work were obtained with financial support of InCom LLC.

Institutional Review Board Statement: Not applicable.

Informed Consent Statement: Not applicable.

Data Availability Statement: Data of the research is available is on request to the corresponding author.

Acknowledgments: The work was carried out using the Center for Collective Use of the North Caucasus Federal University (NCFU) with the financial support of the Ministry of Education and Science of the Russian Federation (project RF ---- 2296.61321X0029, Agreement No. 075-15-2021-687).

Conflicts of Interest: The authors declare no conflict of interest.

Sample Availability: Samples of the research are available from the authors.

\section{Abbreviations}

ABTS: 2,29-azinobis-(3-ethylbenzothiazoline-6-sulfonic acid); MTT, 3-(4,5-dimethylthiazol-2-yl)2,5-diphenyltetrazolium bromide; DMEM, Dulbecco's modified Eagle medium; DMSO, dimethyl sulfoxide; EMEM, Eagle's minimum essential medium; GC-MS, gas chromatography-mass spectrometry; MALDI TOF MS, matrix assisted laser desorption ionization time-of-flight mass spectrometry, TAA, total antioxidant activity; TEAC, Trolox equivalent antioxidant capacity.

\section{References}

1. Kaushik, N. Saponins of Chlorophytum species. Phytochem. Rev. 2005, 4, 191-196. [CrossRef]

2. Patil, S.M.; Chandanshive, V.V.; Tamboli, A.S.; Adsul, A.A.; Yadav, S.R.; Govindwar, S.P. Analysis of genetic variability in endemic medicinal plants of genus Chlorophytum from the Indian subcontinent using amplified fragment length polymorphism marker. Comptes Rendus Biol. 2015, 338, 838-845. [CrossRef] [PubMed]

3. Munyao, J.N.; Dong, X.; Yang, J.-X.; Mbandi, E.M.; Wanga, V.O.; Oulo, M.A.; Saina, J.K.; Musili, P.M.; Hu, G.-W. Complete Chloroplast Genomes of Chlorophytum comosum and Chlorophytum gallabatense: Genome Structures, Comparative and Phylogenetic Analysis. Plants 2020, 9, 296. [CrossRef] [PubMed] 
4. Deore, S.L.; Jajoo, N.B.; Chittam, K.P.; Deshmukh, T.A. Comparative Pharmacognostic, Phytochemical and Biological evaluation between five Chlorophytum species. Pharmacogn. J. 2015, 7, 317-325. [CrossRef]

5. Khare, C.P. Indian Medicinal Plants. In An Illustrated Dictionary; Khare, C.P., Ed.; Springer: Berlin/Heidelberg, Germany, 2007; p. 68. [CrossRef]

6. Yang, X.; Chen, A.; Ma, Y.; Gao, Y.; Gao, Z.; Fu, B.; Sun, F.; Qiao, J.; Li, Q.; Wan, S.; et al. Encyclopedic Reference of Traditional Chinese Medicine; Springer: Berlin/Heidelberg, Germany, 2007; p. 567. [CrossRef]

7. Fan, C.; Jin, H.; Wu, L.; Zhang, Y.; Ye, R.D.; Zhang, W.; Zhang, Y. An Exploration of Traditional Chinese Medicinal Plants with Anti-Inflammatory Activities. Evid. Based. Complement. Alternat. Med. 2017, 2017, 1231820. [CrossRef] [PubMed]

8. Tabuti, J.R.; Lye, K.A.; Dhillion, S.S. Traditional herbal drugs of Bulamogi, Uganda: Plants, use and administration. J. Ethnopharmacol. 2003, 88, 19-44. [CrossRef]

9. Vijaya, N.K.; Chavan, P.D. Chlorophytum borivilianum (Safed musli): A Review. Pharmacogn. Rev. 2009, 3, 154-169.

10. Chauhan, R.; Quraishi, A.; Jadhav, S.K.; Keshavkant, S. A comprehensive review on pharmacological properties and biotechnological aspects of Genus Chlorophytum. Acta Physiol. Plant. 2016, 38, 116. [CrossRef]

11. Thakur, M.; Bhargava, S.; Dixit, V.K. Immunomodulatory Activity of Chlorophytum borivilianum Sant. F. Evid. Based Complement. Alternat. Med. 2007, 4, 419-423. [CrossRef]

12. Giri, S.S.; Sen, S.S.; Chi, C.; Kim, H.J.; Yun, S.; Park, S.C.; Sukumaran, V. Chlorophytum borivilianum Polysaccharide Fraction Provokes the Immune Function and Disease Resistance of Labeo rohita against Aeromonas hydrophila. J. Immunol. Res. 2015, 2015, 256510. [CrossRef]

13. Kaur, R.; Kaur, S. Protective efficacy of Chlorophytum borivilianum root extract against murine visceral leishmaniasis by immunomodulating the host responses. J. Ayurveda Integr. Med. 2020, 11, 53-61. [CrossRef] [PubMed]

14. Thakur, M.; Connellan, P.; Deseo, M.A.; Morris, C.; Dixit, V.K. Immunomodulatory Polysaccharide from Chlorophytum borivilianum Roots. Evid. Based Complement. Alternat. Med. 2011, 2011, 598521. [CrossRef] [PubMed]

15. Kanwar, A.S.; Bhutani, K.K. Effects of Chlorophytum arundinaceum, Asparagus adscendens and Asparagus racemosus on proinflammatory cytokine and corticosterone levels produced by stress. Phytother. Res. 2010, 24, 1562-1566. [CrossRef] [PubMed]

16. Lande, A.A.; Ambavade, S.D.; Swami, U.S.; Adkar, P.P.; Ambavade, P.D.; Waghamare, A.B. Saponins isolated from roots of Chlorophytum borivilianum reduce acute and chronic inflammation and histone deacetylase. J. Integr. Med. 2015, 13, 25-33. [CrossRef]

17. O'Donnell, G.; Bucar, F.; Gibbons, S. Phytochemistry and antimycobacterial activity of Chlorophytum inornatum. Phytochemistry 2006, 67, 178-182. [CrossRef] [PubMed]

18. Abubakar, A.; Nazifi, A.B.; Odoma, S.; Shehu, S.; Danjuma, N.M. Antinociceptive activity of methanol extract of Chlorophytum alismifolium tubers in murine model of pain: Possible involvement of $\alpha 2$-adrenergic receptor and KATP channels. J. Tradit. Complement. Med. 2019, 10,1-6. [CrossRef]

19. Visavadiya, N.P.; Soni, B.; Dalwadi, N.; Madamwar, D. Chlorophytum borivilianum as potential terminator of free radicals in various in vitro oxidation systems. Drug. Chem. Toxicol. 2010, 33, 173-182. [CrossRef]

20. Sharma, G.; Kumar, M. Antioxidant and modulatory role of Chlorophytum borivilianum against arsenic induced testicular impairment. J. Environ. Sci. 2012, 24, 2159-2165. [CrossRef]

21. Narasimhan, S.; Govindarajan, R.; Vijayakumar, M.; Mehrotra, S. Free radical scavenging potential of Chlorophytum tuberosum Baker. J. Ethnopharmacol. 2006, 104, 423-425. [CrossRef]

22. Ashraf, M.F.; Abd Aziz, M.; Stanslas, J.; Ismail, I.; Abdul Kadir, M. Assessment of antioxidant and cytotoxicity activities of saponin and crude extracts of Chlorophytum borivilianum. Sci. World J. 2013, 2013, 216894. [CrossRef]

23. Kenjale, R.D.; Shah, R.K.; Sathaye, S.S. Anti-stress and anti-oxidant effects of roots of Chlorophytum borivilianum (Santa Pau \& Fernandes). Indian J. Exp. Biol. 2007, 45, 974-979. [PubMed]

24. Narasimhan, S.; Govindarajan, R.; Madhavan, V.; Thakur, M.; Dixit, V.K.; Mehrotra, S.; Madhusudanan, K.P. Action of (2->1)Fructo-oligopolysaccharide fraction of Chlorophytum borivilianum against Streptozotocin-Induced oxidative stress. Planta Med. 2006, 72, 1421-1424. [CrossRef] [PubMed]

25. Kumar, M.; Meena, P.; Verma, S.; Kumar, M.; Kumar, A. Anti-tumour, anti-mutagenic and chemomodulatory potential of Chlorophytum borivilianum. Asian Pac. J. Cancer Prev. 2010, 11, 327-334. [PubMed]

26. Shinde, S.S.; Patil, S.M.; Rane, N.R.; Adsul, A.A.; Gholve, A.R.; Pawar, P.K.; Yadav, S.R.; Govindwar, S.P. Comprehensive investigation of free radical quenching potential, total phenol, flavonoid and saponin content, and chemical profiles of twelve Chlorophytum Ker Gawl species. Indian J. Nat. Prod. Resour. 2016, 7, 125-134.

27. Thakur, M.; Thompson, D.; Connellan, P.; Deseo, M.A.; Morris, C.; Dixit, V.K. Improvement of penile erection, sperm count and seminal fructose levels in vivo and nitric oxide release in vitro by ayurvedic herbs. Andrologia 2011, 43, 273-277. [CrossRef]

28. Mahajan, G.K.; Mahajan, A.Y.; Mahajan, R.T. Efficacy of aphrodisiac plants towards improvement in semen quality and motility in infertile males. J. Complement. Integr. Med. 2012, 9, 6. [CrossRef]

29. Rath, S.K.; Panja, A.K. Clinical evaluation of root tubers of Shweta Musali (Chlorophytum borivilianum L.) and its effect on semen and testosterone. Ayu 2013, 34, 273-275. [CrossRef]

30. Kenjale, R.; Shah, R.; Sathaye, S. Effects of Chlorophytum borivilianum on sexual behaviour and sperm count in male rats. Phytother. Res. 2008, 22, 796-801. [CrossRef] 
31. Ray, S.; Chatterjee, K.; De, D.; Ghosh, D. Bioefficacy of hydromethanolic extract of tuber of Chlorophytum borivilianum (Safed Musli) for the management of male infertility in cyproterone acetate-treated albino rats. Andrologia 2014, 46, 659-671. [CrossRef]

32. Thakur, M.; Chauhan, N.S.; Bhargava, S.; Dixit, V.K. A comparative study on aphrodisiac activity of some ayurvedic herbs in male albino rats. Arch. Sex. Behav. 2009, 38, 1009-1015. [CrossRef]

33. Thakur, M.; Bhargava, S.; Praznik, W.; Loeppert, R.; Dixit, V.K. Effect of Chlorophytum borivilianum Santapau and Fernandes on sexual dysfunction in hyperglycemic male rats. Chin. J. Integr. Med. 2009, 15, 448-453. [CrossRef] [PubMed]

34. Das, S.; Singhal, S.; Kumar, N.; Rao, C.M.; Sumalatha, S.; Dave, J.; Dave, R.; Nandakumar, K. Standardised extract of Safed Musli (Chlorophytum borivilianum) increases aphrodisiac potential besides being safe in male Wistar rats. Andrologia 2016, 48, 1236-1243. [CrossRef] [PubMed]

35. Giribabu, N.; Kumar, K.E.; Rekha, S.S.; Muniandy, S.; Salleh, N. Chlorophytum borivilianum (Safed Musli) root extract prevents impairment in characteristics and elevation of oxidative stress in sperm of streptozotocin-induced adult male diabetic Wistar rats. BMC Complementary Altern. Med. 2014, 14, 291. [CrossRef] [PubMed]

36. Giribabu, N.; Kumar, K.E.; Rekha, S.S.; Muniandy, S.; Salleh, N. Chlorophytum borivilianum root extract maintains near normal blood glucose, insulin and lipid profile levels and prevents oxidative stress in the pancreas of streptozotocin-induced adult male diabetic rats. Int. J. Med. Sci. 2014, 11, 1172-1784. [CrossRef] [PubMed]

37. Lakshmi, V.; Kumar, R.; Pandey, K.; Joshi, B.S.; Roy, R.; Madhusudanan, K.P.; Tiwari, P.; Srivastava, A.K. Structure and activities of a steroidal saponin from Chlorophytum nimonii (Grah) Dalz. Nat. Prod. Res. 2009, 23, 963-972. [CrossRef] [PubMed]

38. Visavadiya, N.P.; Narasimhacharya, A.V. Ameliorative effect of Chlorophytum borivilianum root on lipid metabolism in hyperlipaemic rats. Clin. Exp. Pharmacol. Physiol. 2007, 34, 244-249. [CrossRef] [PubMed]

39. Areshidze, D.A.; Timchenko, L.D.; Gulyukin, M.I.; Kozlova, M.A.; Rzhepakovsky, I.V.; Syomin, I.A.; Andreyuk, V.A. Hepatoprotective effect of preparations produced from Chlorophytum comosum (L.) at experimental toxic damage in wistar rats. Pharmacologyonline 2016, 2, 81-90.

40. Areshidze, D.; Timchenko, L.; Kozlova, M. The use of enzymatic hydrolyzate of Chlorophytum comosum with experimental toxic liver damage in rats. Am. J. Biomed. Sci. Res. 2013, 1, 32-36. [CrossRef]

41. Matsushita, H.; Kuwabara, H.; Ishikawa, S.; Mochizuki, M. Apoptosis Induced in Human Cell Lines by a Butanol Extract from Chlorophytum comosum Roots. J. Health Sci. 2005, 51, 341-345. [CrossRef]

42. Tandon, M.; Shukla, Y.N. A bibenzyl xyloside from Chlorophytum arundinaceum. Phytochemistry 1993, 32, 1624-1625. [CrossRef]

43. Deore, S.L.; Khadabadi, S.S. Isolation and characterization of phytoconstituents from Chlorophytum borivilianum. Pharmacogn. Res. 2010, 2, 343-349. [CrossRef]

44. Patil, V.N.; Deokule, S.S. Pharmacognostic study of Chlorophytum tuberosum Baker. Int. J. Ayurveda Res. 2010, 1, 237-242. [CrossRef] [PubMed]

45. Tandon, M.; Shukla, Y.N.; Thakur, R.S. 4-hydroxy-8,11-oxidoheneicosanol and other constituents from Chlorophytum arundinaceum roots. Phytochemistry 1992, 31, 2525-2526. [CrossRef]

46. Mimaki, Y.; Kanmoto, T.; Sashida, Y.; Nishino, A.; Satomi, Y.; Nishino, H. Steroidal saponins from the underground parts of Chlorophytum comosum and their inhibitory activity on tumour promoter-induced phospholipids metabolism of HeLa cells. Phytochemistry 1996, 41, 1405-1410. [CrossRef]

47. Rizvi, M.Z.; Kukreja, A.K.; Bisht, N.S. In vitro propagation of an endangered medicinal herb Chlorophytum borivilianum Sant. et Fernand. through somatic embryogenesis. Physiol. Mol. Biol. Plants 2010, 16, 249-257. [CrossRef] [PubMed]

48. Qiu, S.X.; Li, X.C.; Xiong, Y.; Dong, Y.; Chai, H.; Fransworth, N.R.; Pezzuto, J.M.; Fong, H.H. Isolation and characterization of cytotoxic saponin chloromaloside A from Chlorophytum malayense. Planta Med. 2000, 66, 587-590. [CrossRef] [PubMed]

49. Acharya, D.; Mitaine-Offer, A.C.; Kaushik, N.; Miyamoto, T.; Paululat, T.; Mirjolet, J.F.; Duchamp, O.; Lacaille-Dubois, M.A. Cytotoxic spirostane-type saponins from the roots of Chlorophytum borivilianum. J. Nat. Prod. 2009, 72, 177-181. [CrossRef]

50. Sharma, R.; Thakur, G.S.; Sanodiya, B.S.; Pandey, M.; Bisen, P.S. Saponin: A Wonder Drug from Chlorophytum Species. Glob. J. Res. Med. Plants Indig. Med. 2012, 1, 503-515.

51. Tabopda, T.K.; Mitaine-Offer, A.C.; Paululat, T.; Delemasure, S.; Dutartre, P.; Ngadjui, B.T.; Lacaille-Dubois, M.A. Steroidal saponins from Chlorophytum deistelianum. Phytochemistry 2016, 126, 34-40. [CrossRef]

52. Acharya, D.; Mitaine-Offer, A.C.; Kaushik, N.; Miyamoto, T.; Paululat, T.; Mirjolet, J.F.; Duchamp, O.; Lacaille-Dubois, M.A Steroidal saponins from Chlorophytum orchidastrum. J. Nat. Prod. 2010, 73, 7-11. [CrossRef]

53. Kumar, S.; Kalra, S.; Kumar, S.; Kaur, J.; Singh, K. Differentially expressed transcripts from leaf and root tissue of Chlorophytum borivilianum: A plant with high medicinal value. Gene 2012, 511, 79-87. [CrossRef] [PubMed]

54. Chakraborthy, G.S. Antioxidant Activity of the Successive Extracts of Chlorophytum borivilianum Leaves. Asian J. Chem. 2008, 20,5782-5784.

55. Joshi, A.; Chauhan, R.S. Cytotoxicity studies of Chlorophytum borivilianum against BHK-21 cells. J. Biol. Chem. Res. 2013, 30, 302-309.

56. Dill, V.; Pfaff, F.; Zimmer, A.; Beer, M.; Eschbaumer, M. Adherent and suspension baby hamster kidney cells have a different cytoskeleton and surface receptor repertoire. PLoS ONE 2021, 16, e0246610. [CrossRef]

57. Adhami, S.; Farooqi, H.; Abdin, M.Z.; Prasad, R.; Malik, A.A. Chemical Profiling of Chlorophytum comosum (Thunb.) Jaques by GCMS/LC-ESI-MS and its Antiproliferative Effects on Human Carcinoma Cell Lines. Anticancer Agents Med. Chem. 2020, 21, 1697-1707. [CrossRef] [PubMed] 
58. Pandey, P.; Bajpai, P.; Siddiqui, M.H.; Sayyed, U.; Tiwari, R.; Shekh, R.; Mishra, K.; Kapoor, V.K. Elucidation of the Chemopreventive Role of Stigmasterol Against Jab1 in Gall Bladder Carcinoma. Endocr. Metab. Immune Disord. Drug Targets 2019, 19, 826-837. [CrossRef] [PubMed]

59. Tetko, I.V.; Poda, G.I. Application of ALOGPS 2.1 to predict log D distribution coefficient for Pfizer proprietary compounds. $J$. Med. Chem. 2004, 47, 5601-5604. [CrossRef] [PubMed]

60. Minkiewicz, P.; Iwaniak, A.; Darewicz, M. BIOPEP-UWM Database of Bioactive Peptides: Current Opportunities. Int. J. Mol. Sci. 2019, 20, 5978. [CrossRef] [PubMed]

61. Jandacek, R.J. Linoleic Acid: A Nutritional Quandary. Healthcare 2017, 5, 25. [CrossRef]

62. Choque, B.; Catheline, D.; Rioux, V.; Legrand, P. Linoleic acid: Between doubts and certainties. Biochimie 2014, 96, 14-21. [CrossRef]

63. Carta, G.; Murru, E.; Banni, S.; Manca, C. Palmitic Acid: Physiological Role, Metabolism and Nutritional Implications. Front Physiol. 2017, 8, 902. [CrossRef]

64. Van Rooijen, M.A.; Mensink, R.P. Palmitic Acid Versus Stearic Acid: Effects of Interesterification and Intakes on Cardiometabolic Risk Markers-A Systematic Review. Nutrients 2020, 12, 615. [CrossRef] [PubMed]

65. Sampath, H.; Ntambi, J.M. The fate and intermediary metabolism of stearic acid. Lipids 2005, 40, 1187-1191. [CrossRef] [PubMed]

66. Qi, X.; Tester, R.F. Lactose, Maltose, and Sucrose in Health and Disease. Mol. Nutr. Food Res. 2020, 64, e1901082. [CrossRef] [PubMed]

67. Kluch, M.; Socha-Banasiak, A.; Pacześ, K.; Borkowska, M.; Czkwianianc, E. The role of disaccharidases in the digestion-Diagnosis and significance of their deficiency in children and adults. Pol Merkur Lek. 2020, 49, 275-278.

68. McCall, J.M.; DeCristofaro, C.; Elliott, L. Oral sucrose for pain control in nonneonate infants during minor painful procedures. J. Am. Assoc. Nurse Pract. 2013, 25, 244-252. [CrossRef]

69. Puertolas, M.V.; Fifi, A.C. The Role of Disaccharidase Deficiencies in Functional Abdominal Pain Disorders-A Narrative Review. Nutrients 2018, 10, 1835. [CrossRef]

70. Bhardwaj, M.; Sali, V.K.; Mani, S.; Vasanthi, H.R. Neophytadiene from Turbinaria ornata Suppresses LPS-Induced Inflammatory Response in RAW 264.7 Macrophages and Sprague Dawley Rats. Inflammation 2020, 43, 937-950. [CrossRef]

71. Balamurugan, R.; Duraipandiyan, V.; Ignacimuthu, S. Antidiabetic activity of $\gamma$-sitosterol isolated from Lippia nodiflora L. in streptozotocin induced diabetic rats. Eur. J. Pharmacol. 2011, 667, 410-418. [CrossRef]

72. Li, K.; Yuan, D.; Yan, R.; Meng, L.; Zhang, Y.; Zhu, K. Stigmasterol exhibits potent antitumor effects in human gastric cancer cells mediated via inhibition of cell migration, cell cycle arrest, mitochondrial mediated apoptosis and inhibition of JAK/STAT signalling pathway. J. BUON 2018, 23, 1420-1425.

73. Kangsamaksin, T.; Chaithongyot, S.; Wootthichairangsan, C.; Hanchaina, R.; Tangshewinsirikul, C.; Svasti, J. Lupeol and stigmasterol suppress tumor angiogenesis and inhibit cholangiocarcinoma growth in mice via downregulation of tumor necrosis factor- $\alpha$. PLoS ONE 2017, 12, e0189628. [CrossRef]

74. Ali, H.; Dixit, S.; Ali, D.; Alqahtani, S.M.; Alkahtani, S.; Alarifi, S. Isolation and evaluation of anticancer efficacy of stigmasterol in a mouse model of DMBA-induced skin carcinoma. Drug Des. Devel. Ther. 2015, 9, 2793-2800. [CrossRef] [PubMed]

75. Feng, S.; Dai, Z.; Liu, A.B.; Huang, J.; Narsipur, N.; Guo, G.; Yang, C.S. Intake of stigmasterol and $\beta$-sitosterol alters lipid metabolism and alleviates NAFLD in mice fed a high-fat western-style diet. Biochim. Biophys. Acta Mol. Cell Biol. Lipids 2018, 1863, 1274-1284. [CrossRef]

76. Batta, A.K.; Xu, G.; Honda, A.; Miyazaki, T.; Salen, G. Stigmasterol reduces plasma cholesterol levels and inhibits hepatic synthesis and intestinal absorption in the rat. Metabolism 2006, 55, 292-299. [CrossRef] [PubMed]

77. Chandler, R.F.; Hooper, S.N.; Ismail, H.A. Antihypercholesterolemic studies with sterols: Beta-sitosterol and stigmasterol. J. Pharm. Sci. 1979, 68, 245-247. [CrossRef] [PubMed]

78. Andriamiarina, R.; Laraki, L.; Pelletier, X.; Debry, G. Effects of stigmasterol-supplemented diets on fecal neutral sterols and bile acid excretion in rats. Ann. Nutr. Metab. 1989, 33, 297-303. [CrossRef] [PubMed]

79. Li, C.; Liu, Y.; Xie, Z.; Lu, Q.; Luo, S. Stigmasterol protects against Ang II-induced proliferation of the A7r5 aortic smooth muscle cell-line. Food Funct. 2015, 6, 2266-2272. [CrossRef]

80. Lifsey, H.C.; Kaur, R.; Thompson, B.H.; Bennett, L.; Temel, R.E.; Graf, G.A. Stigmasterol stimulates transintestinal cholesterol excretion independent of liver X receptor activation in the small intestine. J. Nutr. Biochem. 2020, 76, 108263. [CrossRef]

81. Panda, S.; Jafri, M.; Kar, A.; Meheta, B.K. Thyroid inhibitory, antiperoxidative and hypoglycemic effects of stigmasterol isolated from Butea monosperma. Fitoterapia 2009, 80, 123-126. [CrossRef]

82. Wang, J.; Huang, M.; Yang, J.; Ma, X.; Zheng, S.; Deng, S.; Huang, Y.; Yang, X.; Zhao, P. Anti-diabetic activity of stigmasterol from soybean oil by targeting the GLUT4 glucose transporter. Food Nutr. Res. 2017, 61, 1364117. [CrossRef]

83. Lim, J.C.; Park, J.H.; Budesinsky, M.; Kasal, A.; Han, Y.H.; Koo, B.S.; Lee, S.I.; Lee, D.U. Antimutagenic constituents from the thorns of Gleditsia sinensis. Chem. Pharm. Bull. 2005, 53, 561-564. [CrossRef] [PubMed]

84. Aminu, R.; Umar, I.A.; Rahman, M.A.; Ibrahim, M.A. Stigmasterol retards the proliferation and pathological features of Trypanosoma congolense infection in rats and inhibits trypanosomal sialidase in vitro and in silico. Biomed. Pharmacother. 2017, 89, 482-489. [CrossRef] [PubMed] 
85. Walker, C.I.B.; Oliveira, S.M.; Tonello, R.; Rossato, M.F.; da Silva Brum, E.; Ferreira, J.; Trevisan, G. Anti-nociceptive effect of stigmasterol in mouse models of acute and chronic pain. Naunyn Schmiedeberg Arch. Pharmacol. 2017, 390, 1163-1172. [CrossRef] [PubMed]

86. Chen, W.P.; Yu, C.; Hu, P.F.; Bao, J.P.; Tang, J.L.; Wu, L.D. Stigmasterol blocks cartilage degradation in rabbit model of osteoarthritis. Acta Biochim. Pol. 2012, 59, 537-541. [CrossRef] [PubMed]

87. Gabay, O.; Sanchez, C.; Salvat, C.; Chevy, F.; Breton, M.; Nourissat, G.; Wolf, C.; Jacques, C.; Berenbaum, F. Stigmasterol: A phytosterol with potential anti-osteoarthritic properties. Osteoarthr. Cartil. 2010, 18, 106-116. [CrossRef] [PubMed]

88. Antwi, A.O.; Obiri, D.D.; Osafo, N.; Essel, L.B.; Forkuo, A.D.; Atobiga, C. Stigmasterol Alleviates Cutaneous Allergic Responses in Rodents. Biomed. Res. Int. 2018, 2018, 3984068. [CrossRef]

89. Antwi, A.O.; Obiri, D.D.; Osafo, N. Stigmasterol Modulates Allergic Airway Inflammation in Guinea Pig Model of OvalbuminInduced Asthma. Mediat. Inflamm. 2017, 2017, 2953930. [CrossRef]

90. Antwi, A.O.; Obiri, D.D.; Osafo, N.; Forkuo, A.D.; Essel, L.B. Stigmasterol inhibits lipopolysaccharide-induced innate immune responses in murine models. Int. Immunopharmacol. 2017, 53, 105-113. [CrossRef]

91. Ahmad Khan, M.; Sarwar, A.H.M.G.; Rahat, R.; Ahmed, R.S.; Umar, S. Stigmasterol protects rats from collagen induced arthritis by inhibiting proinflammatory cytokines. Int. Immunopharmacol. 2020, 85, 106642. [CrossRef]

92. Sun, J.; Li, X.; Liu, J.; Pan, X.; Zhao, Q. Stigmasterol Exerts Neuro-Protective Effect Against Ischemic/Reperfusion Injury Through Reduction Of Oxidative Stress And Inactivation Of Autophagy. Neuropsychiatr. Dis. Treat. 2019, 15, 2991-3001. [CrossRef]

93. Liang, Q.; Yang, J.; He, J.; Chen, X.; Zhang, H.; Jia, M.; Liu, K.; Jia, C.; Pan, Y.; Wei, J. Stigmasterol alleviates cerebral ischemia/reperfusion injury by attenuating inflammation and improving antioxidant defenses in rats. Biosci Rep. 2020, 40, BSR20192133. [CrossRef] [PubMed]

94. Adebiyi, O.E.; Olopade, J.O.; Olayemi, F.O. Sodium metavanadate induced cognitive decline, behavioral impairments, oxidative stress and down regulation of myelin basic protein in mice hippocampus: Ameliorative roles of $\beta$-spinasterol, and stigmasterol. Brain Behav. 2018, 8, e01014. [CrossRef] [PubMed]

95. Haque, M.N.; Moon, I.S. Stigmasterol promotes neuronal migration via reelin signaling in neurosphere migration assays. Nutr. Neurosci. 2020, 23, 679-687. [CrossRef] [PubMed]

96. Haque, M.N.; Bhuiyan, M.M.H.; Moon, I.S. Stigmasterol activates Cdc42-Arp2 and Erk1/2-Creb pathways to enrich glutamatergic synapses in cultures of brain neurons. Nutr. Res. 2018, 56, 71-78. [CrossRef]

97. Haque, M.N.; Moon, I.S. Stigmasterol upregulates immediate early genes and promotes neuronal cytoarchitecture in primary hippocampal neurons as revealed by transcriptome analysis. Phytomedicine 2018, 46, 164-175. [CrossRef]

98. Park, S.J.; Kim, D.H.; Jung, J.M.; Kim, J.M.; Cai, M.; Liu, X.; Hong, J.G.; Lee, C.H.; Lee, K.R.; Ryu, J.H. The ameliorating effects of stigmasterol on scopolamine-induced memory impairments in mice. Eur. J. Pharmacol. 2012, 676, 64-70. [CrossRef]

99. Tao, C.; Shkumatov, A.A.; Alexander, S.T.; Ason, B.L.; Zhou, M. Stigmasterol accumulation causes cardiac injury and promotes mortality. Commun. Biol. 2019, 2, 20. [CrossRef]

100. Islam, M.T.; de Alencar, M.V.; da Conceição Machado, K.; da Conceição Machado, K.; de Carvalho Melo-Cavalcante, A.A.; de Sousa, D.P.; de Freitas, R.M. Phytol in a pharma-medico-stance. Chem. Biol. Interact. 2015, 240, 60-73. [CrossRef]

101. McGinty, D.; Letizia, C.S.; Api, A.M. Fragrance material review on phytol. Food Chem. Toxicol. 2010, 48, S59-S63. [CrossRef]

102. Farag, M.R.; Alagawany, M.; Bin-Jumah, M.; Othman, S.I.; Khafaga, A.F.; Shaheen, H.M.; Samak, D.; Shehata, A.M.; Allam, A.A.; Abd El-Hack, M.E. The Toxicological Aspects of the Heat-Borne Toxicant 5-Hydroxymethylfurfural in Animals: A Review. Molecules 2020, 25, 1941. [CrossRef]

103. Shapla, U.M.; Solayman, M.; Alam, N.; Khalil, M.I.; Gan, S.H. 5-Hydroxymethylfurfural (HMF) levels in honey and other food products: Effects on bees and human health. Chem. Cent. J. 2018, 12, 35. [CrossRef] [PubMed]

104. Arnous, A.; Makris, D.P.; Kefalas, P. Effect of principal polyphenolic components in relation to antioxidant characteristics of aged red wines. J. Agric. Food Chem. 2001, 49, 5736-5742. [CrossRef] [PubMed]

105. Petropoulos, S.A.; Fernandes, A.; Barros, L.; Ferreira, I.C. A comparison of the phenolic profile and antioxidant activity of different Cichorium spinosum L. ecotypes. J. Sci. Food Agric. 2018, 98, 183-189. [CrossRef] [PubMed]

106. Gartler, S.M. Apparent Hela cell contamination of human heteroploid cell lines. Nature 1968, 217, 750-751. [CrossRef]

107. Lavappa, K.S. Survey of ATCC stocks of human cell lines for HeLa contamination. In Vitro 1978, 14, 469-475. [CrossRef]

108. Smith, K.R.; Hayat, F.; Andrews, J.F.; Migaud, M.E.; Gassman, N.R. Dihydroxyacetone Exposure Alters NAD(P)H and Induces Mitochondrial Stress and Autophagy in HEK293T Cells. Chem. Res. Toxicol. 2019, 32, 1722-1731. [CrossRef]

109. Smith, K.R.; Granberry, M.; Tan, M.C.B.; Daniel, C.L.; Gassman, N.R. Dihydroxyacetone induces G2/M arrest and apoptotic cell death in A375P melanoma cells. Environ. Toxicol. 2018, 33, 333-342. [CrossRef]

110. Petersen, A.B.; Wulf, H.C.; Gniadecki, R.; Gajkowska, B. Dihydroxyacetone, the active browning ingredient in sunless tanning lotions, induces DNA damage, cell-cycle block and apoptosis in cultured HaCaT keratinocytes. Mutat. Res. 2004, 560, 173-186. [CrossRef]

111. Perer, J.; Jandova, J.; Fimbres, J.; Jennings, E.Q.; Galligan, J.J.; Hua, A.; Wondrak, G.T. The sunless tanning agent dihydroxyacetone induces stress response gene expression and signaling in cultured human keratinocytes and reconstructed epidermis. Redox Biol. 2020, 36, 101594. [CrossRef]

112. Janzowski, C.; Glaab, V.; Samimi, E.; Schlatter, J.; Eisenbrand, G. 5-Hydroxymethylfurfural: Assessment of mutagenicity, DNA-damaging potential and reactivity towards cellular glutathione. Food Chem. Toxicol. 2000, 38, 801-809. [CrossRef] 
113. Severin, I.; Dumont, C.; Jondeau-Cabaton, A.; Graillot, V.; Chagnon, M.C. Genotoxic activities of the food contaminant 5hydroxymethylfurfural using different in vitro bioassays. Toxicol. Lett. 2010, 192, 189-194. [CrossRef] [PubMed]

114. Hou, Y.N.; Wang, Y.R.; Zheng, C.H.; Feng, K. Biotransformation of 5-hydroxymethylfurfural into 2,5-dihydroxymethylfuran by Ganoderma sessile and toxicological assessment of both compounds. AMB Express 2020, 10, 88. [CrossRef] [PubMed]

115. Nemes, D.; Kovacs, R.; Nagy, F.; Mezo, M.; Poczok, N.; Ujhelyi, Z.; Peto, A.; Feher, P.; Fenyvesi, F.; Varadi, J.; et al. Interaction between Different Pharmaceutical Excipients in Liquid Dosage Forms-Assessment of Cytotoxicity and Antimicrobial Activity. Molecules 2018, 23, 1827. [CrossRef] [PubMed]

116. Davidson, A.F.; Glasscock, C.; McClanahan, D.R.; Benson, J.D.; Higgins, A.Z. Toxicity Minimized Cryoprotectant Addition and Removal Procedures for Adherent Endothelial Cells. PLoS ONE 2015, 10, e0142828. [CrossRef]

117. Hossler, P.; McDermott, S.; Racicot, C.; Chumsae, C.; Raharimampionona, H.; Zhou, Y.; Ouellette, D.; Matuck, J.; Correia, I.; Fann, J.; et al. Cell culture media supplementation of uncommonly used sugars sucrose and tagatose for the targeted shifting of protein glycosylation profiles of recombinant protein therapeutics. Biotechnol. Prog. 2014, 30, 1419-1431. [CrossRef]

118. Yu, Y.C.; Yu, M.M. Mass spectrum of Heterocycloalkanes of Rhodiola Rosea. 2018. Available online: https:/ / www.researchgate. net/publication/328447521_Mass_spectrum_of_Heterocycloalkanes_of_Rhodiola_Rosea_hongjingtian?channel=doi\&linkId= 5bce9a2b4585152b144ebadb\&showFulltext=true (accessed on 17 December 2021).

119. Clingman, A.L.; Richtmyer, N.K. Aryl Thioglycopyranosides, Aryl Glycopyranosyl Sulfones, and the Novel Oxidation-Acetylation of Aryl 1-Thio- $\beta$-D-glucopyranosides to 6-O-Acetyl- $\beta$-D-glucopyranosyl Aryl Sulfones. J. Org. Chem. 1964, 29, $1782-1787$. [CrossRef]

120. Coatney, G.R.; Cooper, W.C.; Eddy, N.B.; Greenbeeg, J. Survey of antimalarial agents. In Chemotherapy of Plasmodium gallinaceum Infections; Toxicity; Correlation of Structure and Action, 9th ed.; Public health monograph; Government Printing Office: Washington, DC, USA, 1953; p. 214.

121. Hays, J.B.; Sussman, M.L.; Glass, T.W. Inhibition by 6-O-tosyl galactosides of beta-galactoside phosphorylation and transport by the lactose phosphotransferase system of Staphylococcus aureus. J. Biol. Chem. 1975, 250, 8834-8839. [CrossRef]

122. Alsanosy, R.; Alhazmi, H.A.; Sultana, S.; Abdalla, A.N.; Ibrahim, Y.; Al Bratty, M.; Banji, D.; Khardali, I.; Khalid, A. Phytochemical Screening and Cytotoxic Properties of Ethanolic Extract of Young and Mature Khat Leaves. J. Chem. 2020, $2020,7897435$. [CrossRef]

123. Kannan, A.; Hettiarachchy, N.S.; Lay, J.O.; Liyanage, R. Human cancer cell proliferation inhibition by a pentapeptide isolated and characterized from rice bran. Peptides 2010, 31, 1629-1634. [CrossRef]

124. Simmaco, M.; De Biase, D.; Severini, C.; Aita, M.; Erspamer, G.F.; Barra, D.; Bossa, F. Purification and characterization of bioactive peptides from skin extracts of Rana esculenta. Biochim. Biophys. Acta 1990, 1033, 318-323. [CrossRef]

125. Juillerat-Jeanneret, L.; Robert, M.C.; Juillerat, M.A. Peptides from Lactobacillus hydrolysates of bovine milk caseins inhibit prolyl-peptidases of human colon cells. J. Agric. Food Chem. 2011, 59, 370-377. [CrossRef] [PubMed]

126. Tyagi, A.; Tuknait, A.; Anand, P.; Gupta, S.; Sharma, M.; Mathur, D.; Joshi, A.; Singh, S.; Gautam, A.; Raghava, G.P. CancerPPD: A database of anticancer peptides and proteins. Nucleic Acids Res. 2015, 43, D837-D843. [CrossRef]

127. Oh, D.; Shin, S.Y.; Lee, S.; Kang, J.H.; Kim, S.D.; Ryu, P.D.; Hahm, K.S.; Kim, Y. Role of the hinge region and the tryptophan residue in the synthetic antimicrobial peptides, cecropin A(1-8)-magainin 2(1-12) and its analogues, on their antibiotic activities and structures. Biochemistry 2000, 39, 11855-11864. [CrossRef] [PubMed]

128. Emran, T.B.; Rahman, M.A.; Uddin, M.M.N.; Rahman, M.M.; Uddin, M.Z.; Dash, R.; Layzu, C. Effects of organic extracts and their different fractions of five Bangladeshi plants on in vitro thrombolysis. BMC Complementary Altern. Med. 2015, 15, 128. [CrossRef] [PubMed]

129. Ali Redha, A.; Siddiqui, S.A.; Ibrahim, S.A. Advanced extraction techniques for Berberis species phytochemicals: A review. Int. J. Food Sci. Technol. 2021, 56, 5485-5496. [CrossRef]

130. Singh, M.; Shakya, S.; Soni, V.K.; Dangi, A.; Kumar, N.; Bhattacharya, S.M. The n-Hexane and Chloroform Fractions of Piper Betle, L. Trigger Different Arms of Immune Responses in BALB/c Mice and Exhibit Antifilarial Activity Against Human Lymphatic Filarid Brugia Malayi. Int. Immunopharmacol. 2009, 9, 716-728. [CrossRef] [PubMed]

131. Barabanov, P.V.; Gerasimov, A.V.; Blinov, A.V.; Kravtsov, A.A.; Kravtsov, V.A. Influence of nanosilver on the efficiency of pisum sativum crops germination. Ecotoxicol. Environ. Saf. 2018, 147, 715-719. [CrossRef] [PubMed]

132. Siddiqui, S.A.; Blinov, A.V.; Serov, A.V.; Gvozdenko, A.A.; Kravtsov, A.A.; Nagdalian, A.A.; Raffa, V.V.; Maglakelidze, D.G.; Blinova, A.A.; Kobina, A.V.; et al. Effect of Selenium Nanoparticles on Germination of Hordeum Vulgare Barley Seeds. Coatings 2021, 11, 862. [CrossRef]

133. Chang, C.C.; Yang, M.H.; Wen, H.M.; Chern, J.C. Estimation of Total Flavonoid Content in Propolis by Two Complementary Colorimetric Methods. J. Food Drug Anal. 2002, 10, 178-182. [CrossRef]

134. Sumanta, N.; Haque, C.I.; Nishika, J.; Suprakash, R. Spectrophotometric analysis of chlorophylls and carotenoids from commonly grown fern species by using various extracting solvents. Res. J. Chem. Sci. 2014, 4, 63-69.

135. Rajan, K. Analytical Techniques in Biochemistry and Molecular Biology; Springer: New York, NY, USA, 2011; pp. 67-77. [CrossRef]

136. Nawaz, A.; Li, E.; Khalifa, I.; Walayat, N.; Liu, J.; Muhammad Ahsan, H.; Irshad, S.; Barakat, H.; Lorenzo, J.M.; Pateiro, M.; et al. Effectof Structurally Different Pectin onDough Rheology, Structure, Pastingand Water Distribution Properties of Partially Meat-Based Sugar Snap Cookies. Foods 2021, 10, 2692. [CrossRef] 
137. Hazra, B.; Biswas, S.; Mandal, N. Antioxidant and free radical scavenging activity of Spondias pinnata. BMC Complementary Altern. Med. 2008, 8, 63. [CrossRef] [PubMed]

138. Moualek, I.; Aiche, G.I.; Guechaoui, N.M.; Lahcene, S.; Houali, K. Antioxidant and anti-inflammatory activities of Arbutus unedo aqueous extract. Asian Pac. J. Trop. Biomed. 2016, 6, 937-944. [CrossRef]

139. Rao, A.S.V.G.; Reddy, S.G.; Babu, P.P.; Reddy, A.R. The antioxidant and antiproliferative activities of methanolic extracts from Njavara rice bran. BMC Complementary Altern. Med. 2010, 10, 4. [CrossRef] [PubMed]

140. Piskov, S.; Timchenko, L.; Grimm, W.D.; Rzhepakovsky, I.; Avanesyan, S.; Sizonenko, M.; Kurchenko, V. Effects of various drying methods on some physico-chemical properties and the antioxidant profile and ACE inhibition activity of oyster mushrooms (Pleurotus ostreatus). Foods 2020, 9, 160. [CrossRef] [PubMed]

141. Rzhepakovsky, I.; Siddiqui, S.A.; Avanesyan, S.; Benlidayi, M.; Dhingra, K.; Dolgalev, A.; Enukashvily, N.; Fritsch, T.; Heinz, V.; Kochergin, S.; et al. Anti-arthritic effect of chicken embryo tissue hydrolyzate against adjuvant arthritis in rats (X-ray microtomographic and histopathological analysis). Food Sci. Nutr. 2021, 9, 5648-5669. [CrossRef] [PubMed]

142. Heikal, A.; Elsebai, M.; Salama, A.; Taha, H. Comparative study between in vivo- and in vitro-derived extracts of cactus (Opuntis ficus-indica L. Mill) against prostate and mammary cancer cell lines. Heliyon 2021, 7, e08016. [CrossRef] 